\title{
Wide Applications of Chloroquine Other Than Antimalarial
}

\author{
Baraa G. Alani1 ${ }^{1}$ Ameer H. Alwash' ${ }^{1}$, Ismail T. Ibrahim ${ }^{1,2}$ \\ ${ }^{1}$ Faculty of Pharmacy, AL-Bayan University, Iraq, Baghdad \\ ${ }^{2}$ Hot Lab Center, Atomic Energy Authority, Cairo, Egypt \\ Email: ismailtaha_73@yahoo.com
}

How to cite this paper: Alani, B.G., Alwash, A.H. and Ibrahim, I.T. (2020) Wide Applications of Chloroquine Other Than Antimalarial. Pharmacology \& Pharmacy, 11, 251-281.

https://doi.org/10.4236/pp.2020.1110022

Received: September 15, 2020

Accepted: October 27, 2020

Published: October 30, 2020

Copyright $\odot 2020$ by author(s) and Scientific Research Publishing Inc. This work is licensed under the Creative Commons Attribution International License (CC BY 4.0).

http://creativecommons.org/licenses/by/4.0/

(c) (i) Open Access

\begin{abstract}
Chloroquine (CQ) was and still considered as the most common agent in the treatment and prophylaxis of malaria, it also possesses many different pharmacological and biological activities that make it able to be used as a therapy or adjuvant therapy for many types of diseases. CQ exhibits anticancer activity alone or as adjuvants with other agents against many kinds of tumors. Its activities also were approved as an anti-inflammatory agent in rheumatoid and other autoimmune diseases like systemic lupus and rheumatic arthritis. Its' important role in the improvement of many metabolic disorders like hypertension, hyperglycemia, and lipid profile disturbances was also established. CQ can act against different microbial infections such as many types of viruses, bacteria and fungus by different mechanisms of action. Furthermore, its dermatological role in the treatment of many skin diseases was demonstrated. Recently, CQ showed a very responsive role in curing and prevention of the covoid-19 virus. This review summarizes intensively the multiple therapeutic applications of CQ and discusses the possible mechanisms of action for these applications.
\end{abstract}

\section{Keywords}

Chloroquine, Antimalarial, Anticancer, Autophagy

\section{Introduction}

Chloroquine (CQ) is 4-aminoquinoline that has been used for more than 70 years as an antimalarial agent. Its development was started from natural product as its distance precursor quinine was isolated from crude extract of cinchona bark that was been used for reducing fever and malaria for long time [1]. CQ had been synthetized since 1934 by German Farbnindustrie Bayer Laboratories [Figure 1 and Figure 2] [2]. CQ was considered the drug of choice for malarial 
infection for several years till its antimalarial role was reduced by emergence of CQ resistant strains of malarial parasite [2]. CQ is often used alone or together with other compounds to treat many biological disorders other than malaria, such as cancer, inflammatory conditions, hypertensive crises in some cases, high level of blood sugar, dyslipidemia, and different microbial diseases [3] [4]. For a long time it was used in the clinic to treat autoimmune diseases like systemic lupus erythematosus (SLE) and rheumatoid arthritis (RA) by inhibition of the immune system and by its anti-inflammatory properties [5] [6]. Its potent cytotoxic effects against different types of cancer such as colorectal, lung, breast, hepatocellular and human cervical cancer were observed [7] [8]. The weak basicity of CQ molecule with pKas of 8.4 and 10.2 [9] [10] makes it able to accumulate in acidic organelles such as lysosomes, endosomes, Golgi apparatus and interfere with the activity and hydrolysis of the lysosomal enzymes by increasing the $\mathrm{pH}$ lumens of these organelles, therefore makes inhibition to the autophagy process which is involved in many biological disorders [11]. Short term administration of CQ may not induce toxicity but longer exposure has been associated with some dangerous side including irreversible retinal toxicity, bone marrow suppression, cardiomyopathy and hypoglycemia [12] [13]. Hydroxychloroquine sulfate (HCQ), is a famous derivative of CQ, was first synthesized in 1946 by addition a $(\mathrm{OH})$ functional group to $\mathrm{CQ}$ pharmacophore that make it less toxic by $(\sim 40 \%)$ than original CQ in animals trials (Figure 2) [14]. HCQ is still widely available to treat autoimmune diseases, such as rheumatoid arthritis and systemic lupus erythematous. It is important to say that Chloroquine and Hydroxychloroquine share similar mechanisms of acting and chemical structures and both of them are weak bases and immune-modulators [15]. Although there are many reviews about Chloroquine and its therapeutic effects on different diseases and disorders, the majority of them focus on a limited therapeutic strategy with its mechanisms of action by which can improve or treat specific disorders such as; anticancer or antimicrobial etc. This study was conducted to cover in more details as possible as diseases and disorders that CQ and HCQ could be used to treat them as well as the mechanisms by which they can manage them. It also extended to show the most observed side effects of CQ.

\section{Therapeutic Indications of CQ and HCQ}

\subsection{Anticancer}

Cancer means lose the cellular ability to control and regulate their cycle and gain the ability of unlimited cell proliferation, division that finally produce a mass of cells called tumor [16]. Cancers have many different mechanisms and molecules to enhance their growth and metastasis by enhancing malignant cells to cope with the bad micro-environmental conditions like hypoxia and low nutrients [17].

Anticancer activity of CQ and HCQ was well established and demonstrated in-vivo on colon cancer, lung and breast cancer or in-vitro on cancer cell lines. 
Natural pathways

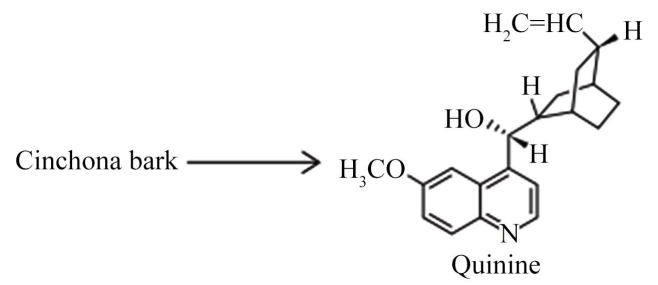

Figure 1. Quinine structure (2).

Synthetic pathways

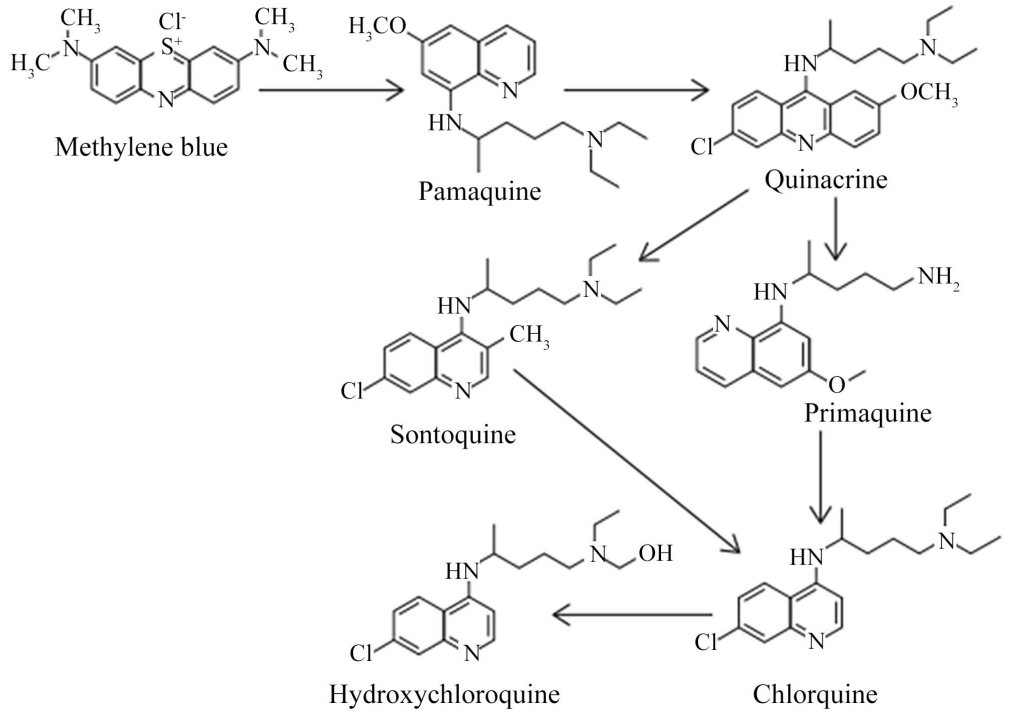

Figure 2. Synthetic pathways of CQ and HCQ (2).

Also, they have excellent potential as cancer-specific chemosensitizer for combination therapy as an adjuvant with other anticancer agents [18].

\subsubsection{Mechanism of Anticancer Effect of CQ, HCQ}

There are multiple hypotheses proposed on how CQ, HCQ exert their anticancer activity when given as mono or adjuvant therapy. For their anticancer activity, CQ and HCQ have multiple mechanisms of action that might complement each.

\section{1) Inhibition of Autophagy}

The main mechanism to which, the anticancer effect of CQ was attributed is inhibition of autophagy (self-eating) [19]. Autophagy is a biological process by which cytoplasmic organelles are eliminated by lysosomes that contain lysosomal degradation enzymes. Up to date, there are three types of autophagy are known micro-autophagy, macro-autophagy, and chaperone-mediated autophagy. They are different by their initiation, mechanisms involved in, and destructive mode during delivery to the lysosome [17] [18]. Autophagy mostly referred to macro-autophagy, is survival mechanisms when cells undergo stress and unsuitable conditions like increasing temperature, low nutrients level, or diminishing amount of oxygen needed. That means autophagy plays important role in biological processes by keeping the hemostasis of the cells [19] [20]. In anoth- 
er side autophagy also having a harmful role that it may contribute to several human disorders like cancer, neurodegenerative diseases like Alzheimer and Parkinson [21]. Autophagy may be implicated in both innate and adaptive immune system defense. It also presents during the total different inflammatory steps and it has been eliminated many cellular invaders like viruses, bacteria, and parasites.

There are two opposite hypotheses on the role of autophagy in cancer. The first suggests that autophagy may promote cancer cell survival [22] [23] [24], but the other suggests the opposite that it may participate in the inhibition of malignancy and limit cancer cells ability to accumulate genotoxic reactive oxygen species [25]. The last one explains the main mechanism of the anticancer effect of CQ and HCQ.

First hypothesis, indicates that the suppression of autophagy can enhance oncogenesis through alteration of the metabolic pathways and produce oxidative stress, that totally lead to helpless mitochondrial turnover [26] [27], inducing genetic instability (which is a consequence of oxidative stress) [28] [29] [30], enhancing Oncogenes impairment to induce senescence, (a process that blocks the malignant cells proliferation permanently while allows their turnover by immune cells) [31] [32] [33]. For this hypothesis, the treatment approach that able to enhance the autophagy process, will be a promising strategy for cancer progression inhibition.

On other hand, the second hypothesis states that autophagy able to facilitate tumor progression and neoplasm establishment [34] by enhancing their coping with the micro-environment hard conditions through providing a source of energy and nutrients to abnormal cell [35] preserving both functions of mitochondria which are controlling the quality of its network and providing metabolic substrate from mitochondria metabolism [36] and finally decreasing the accumulation of potentially cytotoxic entities like reactive oxygen species [37] [38] [39] [40]. According to this hypothesis; the treatment strategy that works to make suppression to autophagy is effective as anticancer therapy or adjuvant therapy [41] [42].

To set in between some types of cancer may be enhanced with autophagy and other could be inhibited with it [43].

CQ, HCQ as weak bases having good safety profile [43], and become protonated in acidic compartments like lysosome and late endosome. It can fuse with these acidic compartments resulting in blocking the flux of stimulating autophagy [44] that will lead to inhibition of lysosomal activity of the autolysosome, hence stopping the degradation. Therefore there is no energy supplying through autophagy pathway because autophagy can promote cancer according to $2^{\text {nd }}$ hypothesis, cancer progression can be stopped by stopping it.

\section{2) Other mechanisms:}

Chloroquine showed additional mechanisms for cancer treatment other than autophagy inhibition.

CQ may also enhance the blood vessels normalization which results to reduce 
the tumor hypoxia through improving the functional and structural features of tumor blood vessels [45] [46] since the appearance of disorganized and dysfunctional blood vessels is the most important feature of many cancers, since they become permeable and enhance the facilities of tumor invasion and progression. In addition CQ can improve these vessels by decreasing the density and tortuosity of tumor vessels that result in improvements in endothelial cell arrangement and formation of tight junction, it also contributes to reducing the leakiness of tumor vessels and elevates their perfusion. It is important to say that the normalization of tumor vessels also enhance the efficacy and delivery of other chemotherapeutic agents [47]. Therefore this action reduces the survival capacity of cancer cells in the blood stream and becomes unable to be metastasized. Because of conformational changes that the autophagy provides blockage of cancer cells will reduce the metastatic propagation rather than prevention.

CQ was shown to suppress pancreatic ductal adenocarcinoma (PADC) and cancer stem cells (CSCs) which are known to be resistant to many medicines and promote tumor progression and metastasis [48]. In animal of PADC, Chloroquine showed its ability to target CSCs by inhibition of signaling pathways that driven by chemokine, leading to suppression of signal transducer and activator of transcription 3 (STAT3) and extracellular signal kinase (ERK), that have a very critical role in metastatic spread [49]. It is able to block epithelial mesenchymal transition in CSCs. Moreover, it can target CSCs in triple-negative breast cancer via down-regulation of multiple signaling pathways like STAT3 that produce decreasing in CSCs [50].

\section{a) Interference with the $\mathrm{p} 53$ pathway}

The tumor suppressor protein p53 plays an essential role in maintaining an error-free genome and inducing cell death in case the damage is irretrievable. Therefore, it is a key protein in the prevention of tumor development [51] [52]. Both in vitro and in vivo research has indicated that CQ can stabilize the p53 protein and activate the $\mathrm{p} 53$-dependent transcription of pro-apoptotic genes. So CQ intercalates in DNA, which leads to structural changes and thus induction of p53 [53] [54] [55] [56] [57].

\subsubsection{CQ as Adjuvant}

Adjuvant CQ is a promising candidate for combination with a variety of cytotoxic agents for the prevention of CSCs driven tumor progression [58]. CQ as adjuvant uses is also due to its ability to sensitize cancer cells to other therapeutic agents by alteration of non-CSC-specific signaling pathways. Treatment with CQ has been shown to improve Cisplatin therapeutic efficacy to DNA damaging and mammalian target rapamycin (mTOR) inhibitor in breast cancer cells [59]. This chemo-sensitization being independent of autophagy inhibition mechanism, as exposure to the autophagy inhibitor Bafilmycin failed to decrease cell viability. In addition, blocking of genes that enhance autophagy like autophagy related protein 12 (Atg 12) and Beclin-1, cannot resemble CQ effects [60]. The most effective mechanism by which CQ can induce drug sensitization include 
DNA intercalation and promote the activation of ataxia telangiectasia mutated (ATM) and P53 [61].

CQ can also penetrate the malignant cells and enhance the radiation response of tumor cells culture. It was also found that CQ can effectively sensitize multi-drug resistance tumor cells to certain anticancer agent [62].

Finally, CQ as a drug act by anti-autophagy pathway or other mechanisms it becomes a very useful therapy to treat many types of cancer like pancreatic adenocarcinoma, prostate cancer, breast cancer, ovarian cancer and renal cell carcinoma [63].

\subsection{Anti-Inflammatory}

CQ has been used as an anti-inflammatory drug for systemic lupus erythematous (SLE) and rheumatoid arthritis (RA) by modulating the immune system [64] [65]. SLE is an autoimmune disorder that may affect a number of organs and tissues of the body associated with skin lesions [66].

Many studies demonstrated that the administration of CQ can inhibit angiogenesis and a significant decrease of dermal blood vessels [67]. Under in vitro conditions, it can induce apoptosis of human endothelial cells and decrease cells proliferation and reducing the levels of angiogenesis [68]. It is able to improve and decrease the sign and symptoms of SEL in joints and epidermal lesions [69]. CQ seems to be an anti-angiogenic agent by decreased expression of VEGF and CD34+ blood vessel number [67]. RA is a chronically progression systemic autoimmune disease associated with extra-articular manifestations like malaise and fatigue [70]. RA had been reported to affect near to $1 \%$ of adults population of affected regions [71] [72]. This disease varies from simple self-limited to sever and joint destruction with intense physical disability and multiple morbidities [73]. Many immune modulators like pro-inflammatory cytokines play a critical role in RA pathophysiology [74]. Native T cells differentiate into Th cells which result in potent cytokine IL-17 production that promotes synovitis. B cells are also involved in pathogenic process by antigen presentation to self-antibodies and cytokine productions [75] [76]. These manifestations of RA are both locally and systemically and describe an inflammatory condition [77].

\section{Mechanism of Anti-Inflammatory Effect}

Different modes of action are explained the anti-inflammatory effects of Chloroquine, mostly are approved by in-vitro studies. The relations between the therapeutic efficacy, mode of actions and safety were observed in-vivo [78]. The most essential mode of action of this compound is the ability to interference with the autophagy and lysosomal activity by inhibition their function, it can make destabilize lysosomal membrane and stimulate releasing of its enzymes inside the cells [79]. This lysosomal activity inhibition might inhibit lymphocytes function that results in immunomodulatory and anti-inflammatory effects (exactly anti-rheumatic effects) [80].

Inhibition signaling pathways are another mode of action of CQ which can 
produce own anti-inflammatory action. This mechanism is done by the interference of this compound with the activity of cyclic guanosine monophosphate adenosine monophosphate (cyclic G-AMP) synthase [81], in which when it being stimulated, it able to enhancing IFN genes pathway which is the major source of type I IFN response. IFN-I is the gene that is strongly implicated in pathogenesis of many inflammatory and autoimmune disorders like RA [82] [83]. So G-AMP inhibitor like Chloroquine is suitable therapy for this inflammatory rheumatic pathway [84]. The other anti-rheumatic mode of action of Chloroquine is summarized by reducing the inflammatory cytokines by various cells type. In in-vitro study; this drug able to inhibit the production of IL-1, IL-6 and TNF in mononuclear cells [85].

Also anti-inflammatory effect of CQ may be achieved through inhibition of arachidonate cyclooxygenase and inhibition of PG synthesis. The anti-inflammatory effectiveness of CQ could be also partly explained by its PG antagonist activity recognized in the mesenteric vascular preparation [86]. CQ suppressed the production of $\mathrm{PGD}_{2}$ and $\mathrm{PGE}_{2}$ in a dose-dependent fashion. This suppression was due to a cyclooxygenase inhibition, since the formation of the prostaglandins from exogenous endo-peroxide $\mathrm{PGH}_{2}$ was unaffected.

$\mathrm{CQ}$ is an inhibitor of the cutaneous cyclooxygenase, and this effect may contribute to its anti-inflammatory action in various dermatological disorders [87].

Many researches find that using Chloroquine for RA treatment can reduce the infiltration in joints as well as the general pain, and can increase the physical function of the patients [88].

\subsection{Anti-Atrial Fibrillation}

Atrial fibrillation (AF) is the most heart rhythm abnormality, its incidence may elevate with age [89] [90]. AF is defined as a supraventricular tachyarrhythmia as a result of uncontrolled atrial activation with atrial mechanical function deterioration [91]. The electrocardiographic findings show the alteration of P-waves with fibrillatory or oscillatory waves of various amplitudes, sizes and timing. AF is responsible for significant mortality and morbidity cases as a result of cardiac function impairment and increasing the rate of stroke risk.

Many studies suggest that blocking the inward rectifiers through a specific condition, it become useful antiarrhythmic therapy for atrial and ventricular tachy-arrhythmias [92] [93] [94]. Since 1950, Chloroquine was noticed to have a potent antiarrhythmic effect against atrial and ventricular tachyarrhythmia [95].

\section{Mechanism of Anti-Atrial Fibrillation}

CQ act as antiarrhythmic by mechanism of blocking the heteromers of the G-protein-gated inward rectifier potassium channel subunits Kir2.1, Kir3.1 and Kir6.2 responsible for the inward-rectifier $\mathrm{K}+$ current (/K1), the acetylcholine-sensitive $\mathrm{K}+$ current (/KACh), and the ATP-sensitive K+ current (/KATP) respectively. Also, it able depolarizes the RMP and increases automaticity, which can be explained by its blocking effects on /K1. The latter may enhance FDs un- 
derlying a triggered activity mechanism [96].

\subsection{Antihypertensive Effect}

Essential hypertension is a systemic and local vascular inflammation [97]. However immune system may also participate in hypertension pathogenesis [98]. Therefore some hypertension cases are a result from some autoimmune disorders [99]. The loss of immunological tolerance may increase the possibility of hypertension [100] [101]. It is important to mention that several autoimmune diseases such as rheumatoid arthritis and systemic lupus erythematosus is characterized by cardiovascular diseases like hypertension and endothelial dysfunction [102] [103].

Chloroquine had been used in treatment of many autoimmune disorders [104] [105] and currently it is stilled among the first-line therapy for these conditions [106]. Chloroquine may have very promising results in patients with hypertension associated with some autoimmune disease [107].

\section{Mechanism of Antihypertensive Effect}

According to Cameron G. McCarthy et al. (2017), Chloroquine having different novel anti-hypertension mechanism in vasculature of spontaneously hypertensive rats, which consist of inhibition of cyclooxygenase-dependent contraction to acetylcholine, reduction of vascular and systemic generation of reactive oxygen species (ROS), improvement of nitric oxide bioavailability, and decreasing the matrix metalloproteinase enzyme (MMP2). All of these mechanisms collectively could reduce blood pressure and ameliorate the hypertensive vascular dysfunction [108] [109].

\subsection{Hypoglycemic Effects}

Diabetes mellitus (DM) defines as a chronic metabolic disease due to defect in insulin secretion [110], it characterized by permanent rising of blood sugar. DM affects millions of people in the world despite the presence of many anti-diabetic agents [111] [112].

Many studies proved that CQ and HCQ have beneficial antidiabetic effects. The anti-diabetic effect of them was firstly diagnosed in 1984 in patients with type 2 diabetes mellitus, when it showed a great reduction in the insulin dose required [113]. Moreover, a long term treated with CQ was found to be beneficial to reduce glycated hemoglobin ( $\mathrm{HbA1C})$ in diabetic patients [114].

\section{Mechanism of Hypoglycemic Effects}

CQ can inhibit insulin degradation in a way which enhances its own metabolic effect and sensitivity [115] [116]. Its main role in metabolism of insulin is through augments the connection between insulin and its receptor (tyrosine kinase), the half-life of insulin receptor complex and prologs the activity insulin [117] [118]. According to different studies about this subject, it has different effects on insulin metabolism. Thus in diabetes mellitus1 (DM1) CQ can improve 
glucose tolerance [119], elevate peripheral glucose disposable and reduce insulin metabolic clearance rate [120]. While in the case of diabetes mellitus 2 (DM2), it is able to decrease the insulin resistance [121] by inhibiting degradation of the latter. The closest explanation to truth for glucose-lowering effect of this agent is that CQ can stabilize intracellular lysosome and slow the breakdown of bond between insulin and its receptor [122]. CQ is an acid trophic molecule, therefore when intracellular lysosomal concentration becomes high with it, then the intracellular $\mathrm{pH}$ value increased thus will produce inactivation of proteolytic enzyme (insulinase) which responsible for both insulin degradation and producing recirculation of substantial proportion of insulin in its active form [123] [124]. CQ also can improve insulin sensitivity and decrease its resistance through indirect effect of reducing inflammation [125]. Moreover, CQ was reported to have good effects in enhancing insulin sensitivity by activation of protein kinase B resulting in an increase of glucose uptakes and glycogen synthesis [126].

\subsection{Anti-Lipidemic Effect}

Dyslipoproteinemia is the major factor in the development of atherosclerotic process in SEL. Hyperlipidemia seems to be a common finding since it has been detected in many cases of SLE [127] [128]. Nephrotic syndrome and renal failure are the secondary cause of lipoprotein abnormalities because they can induce disturbances in lipid metabolism pathways. There are many evidences that demonstrate the effects of CQ on lipid metabolism [129]. CQ shows an effective inhibitory action on cholesterol synthesis [130].

\section{Mechanism of Anti-Lipidemic Effect}

There are several mechanisms that CQ can use to produce lipid-modifying effect. CQ could reduce the LDL (low density lipoprotein) serum level through up-regulation of LDL-C receptors that may cause an enhancement to remove plasma lipoprotein [131] [132] [133]. Many studies have reported that the favorable effects of CQ on serum lipid levels manifested by; reducing LDL-C, total cholesterol (TC), increasing in high-density lipoprotein (HDL-C), and decreasing in triglyceride level (TGs) [134] [135] [136] [137].

Reduction of Apolipoprotein b lipoprotein is investigated through using this agent as a treatment with RA and SEL treated patients [138]. One of them indicates that because it is a weak base compound, that makes it able to accumulate in high amount inside the acid intracellular organelles such as lysosomes [139] and cause a reduction in secretion of VLDL which is one of a lysosomal function. In addition, this agent inhibits the enzyme involved in cholesterol biosynthesis pathway (2, 3 oxidosqualene cyclase) [140]. CQ enhances LDL receptors activity by inhabitation of lysosomal hydrolysis of cholesterol esters. In animal model, there was a suggestion that this medicine may produce antithrombotic effects [141].

The mechanism of action of CQ may be also related to interfering action with 
lysosomal activity, inhibition of antigen presentation and toll-like receptor signaling [142]. On the basis of these mechanisms of actions of this drug, the experimental data suggest that it can produce productive effects on cardiovascular disease. Indeed, its action on the lysosome able to decrease insulin degradation levels [143] and overcome cholesterol synthesis [144]. CQ can also elevate the level of LDL receptors in the liver, as a result, increasing the catabolism plasma LDL and lowering the plasma cholesterol concentration [145].

\subsection{Antimicrobial Effects}

\subsubsection{Antimalarial Effect}

CQ was registered during the first part of the 20th century as an effective quinine subunit and the drug of choice to treat malarial infection [146]. It was approved to be the most effective and successful antimalarial agent according to worldwide scale because the wide deployment coinciding with the geographical distribution of Plasmodium and it has a high efficacy against parasitic infection toxicity [147].

CQ also gained an interest in the field of other infectious diseases [148]. In-vitro data suggest the concept by which this agent can produce effects against all intracellular organisms, which can multiply and grow inside the acidic environment [147].

\section{1) Mechanism of antimicrobial effect}

There are multiple mechanisms of action for CQ for different microbial infections but they are varying according to the pathogens, although they do not have been improved for all pathogens, CQ enters cells as a non-protonated form where it becomes protonated according to Henderson-Hasselbach law in a reverse way to the $\mathrm{pH}$ [149]. So CQ becomes concentrated inside acidic organelles like Golgi vesicles, endosome, and lysosome [148]. There are two main mechanisms of action of CQ as antimicrobial agent, first, is the alkalinisation of acid vesicles inside cells that is infected by intracellular microorganisms like bacteria and fungi. Second, is the alteration of post-translation changes of newly synthesized protein in cells that infected by viruses.

\subsubsection{Anti-Intracellular Parasites}

The evidence of using CQ in treating infections other than malaria was described the first time in vitro and in vivo with $\mathrm{Q}$ fever model caused by Coxiella burnetii ( $C$. burenti). Also, CQ is very harmful to different intracellular bacterial growths such as T. whipplei and Legionella pneumophila and others [150] [151].

There are a wide number of suggestions about the environment of low $\mathrm{pH}$ within the phagosomal compartments of the cell, which is the most important condition for high number of intracellular pathogens to access iron of cell to their growth and multiply [152] [153].

Mechanism of action of CQ in cellular biology, initially by manipulation of the $\mathrm{pH}$ of acidic vacuoles, in which, these intracellular parasites multiply, growths and lives. 
Other types of bacteria like Legionella pneumophila and Tropheryma whipplei (the microbe of Whipple disease which able to multiply inside phagosomes), are inhibited by CQ since an increasing the intravascular $\mathrm{pH}$ will reduce the viability of this bacteria [154].

Francisella tularensis, which is the pathogen responsible for tularemia, it had been shown to be dramatically inhibited by CQ in vitro by the effect of this agent through mechanism of dose-dependent manner [153].

Regarding to Mycobacterium species, Chloroquine can inhibit its growth by increasing the intracellular alkalinity and decrease the level of iron availability as so it does with L. pneumophila [152].

\subsubsection{Extracellular Infections}

In case of Staphylococcus aureus and other some bacterial species, the addition of Chloroquine (a lysosomotropic alkalinizing agent) enhance the intracellular killing ability of some antibiotics like levofloxacin and moxifloxacin. CQ can enhance the bactericidal activity and potency of levofloxacin and moxifloxacin when their $\mathrm{pH}$ is neutralized from 5 to 7.4. It was reported that the low $\mathrm{PH}$ of intra-phagolysosomal can affect the ability of these antibiotics to kill intracellular bacteria, and this also includes other bacteria like Salmonella enterica, Escherichia coli, Bacillus anthracis, Brucella abortus, and many others [155] [156].

\subsubsection{Fungal Infections}

CQ showed effectiveness as antifungal against fungal infection like Histopasma capslatum, and Cryptococcus neoformans.

There are some different mechanisms of action of CQ according to fungus type. $H$. capslatum is survived inside mammalian phagolysosome and maintained the phagosomal PH of 6.5 [157] through inhibiting phagolysosomal fusion [158] and buffering the phagosomal PH [159], that would cause a restriction in iron concentration within the phagolysosome [160]. It can kill C. neoformans by mechanism independent of iron deprivation [161] [162]. Although, C. neoformans can maintain the phagolysosomal PH at 5.1 [163], treatment with $\mathrm{CQ}$ can cause an increase in the phagolysosomal $\mathrm{pH}$ that will cause an inhibition to its growth at alkaline PH [162]. CQ has an ability to kill the Aspergillus fumigatus using PH dependent mechanism [163], and inhibit growth of Penicillum marneffei [161] (an opportunistic fungus in acquired immune deficiency syndrome (AIDS) patient) by elevation the intra-vacuolar $\mathrm{pH}$ and making some disruptions in metabolic processes [164] [165]. The reduction in intracellular iron level results in an impaired function of many cellular enzymes that will lead to subsequent deleterious effects on major and essential steps of biological and metabolic processes such as DNA cellular replication or gene.

\subsubsection{Antiviral Activities}

Chloroquine also have antiviral activity exerted by increasing $\mathrm{pH}$ degree within acidic organelles like lysosomes, endosomes, and Golgi vesicles, this action can appear by either one form of two mechanism chooses; firstly it might responsible 
for inhibition the viral important and critical steps, that low $\mathrm{pH}$-dependent required for viral entry to the host cells. Indeed, there are many viruses that have $\mathrm{PH}$-dependent conformational alterations that stimulate fusion, penetration and un-coating, and it is crucial for endocytosis because of the acidification that occurs inside endosomal pathway [166]. Thus the antiviral effect done by this mechanism is related to types of viruses that use endosomes for cell entry [167]. According to [168], Chloroquine, by raising the lysosomal PH above the level required can inhibit the un-coating step, which is the most essential step in induction fusion between lysosomal membrane and viral envelop of influenza $B$ virus and hepatitis A virus (HAV) [169], because it is a pH-dependent step. Secondly, it has an ability to inhibit viral envelops glycoprotein post-translational modifications by glycosyl transferases and protease inside endoplasmic vesicle and trans-Golgi network [170] [171]. These enzymes are needed low $\mathrm{pH}$ values for their activation and function, therefore the administration of this medicine might lead to reducing viral infectivity by impairing the maturation of viral envelop like Flaviviridae viruses [172]. Relative to its effectiveness against HIV-1 activity, Chloroquine is making an alteration to the glycosylation pattern and to the charges of amino acid in several regions of glycoprotein (gp 120) [173] [174]. The alteration of immune escaping and broadening of antibody repertoire can be provided by reducing the number of potential N-linked glycosylation sites inside the V3 region of gp120 [174]. CQ can reduce the infectivity of HIV-1 newly produced and the ability of that virus-infected cell to form syncytia which have a relation with structural modification in gp120. CQ may be responsible for biosynthesis inhibition of sialic acid (component of HIV-1 envelop glycoprotein) by inhibition of some specific cellular enzymes that have been involved in the sialic acid biosynthesis pathway [175].

Chloroquine may also have indirect antiviral effects by preventing the spread of severe acute respiratory syndrome (SARS) associated coronavirus $(\mathrm{CoV})$ in cell culture through interfering with terminal glycosylation of cellular receptor, angiogenesis converting enzyme2 (ACE2) [176], and sialic acid (a component of SARS-CoV and orthomyxoviruses receptors [177]. Moreover, it has immunemodulatory effects, where they cause decreasing the production of tumor necrosis factor $\alpha$ and interleukin6, which enhance the inflammatory reactions of many viral infections [178]. Chloroquine decreased viral infectivity by impaired envelop maturation like Flaviviridae viruses (172]. The anti-HIV-1 activity is through alteration of the glycosylation pattern and amino acid charge within several regions of the gp120 viral envelops protein [173] [174].

\subsubsection{CQ and Covid-19}

Coronaviruses are big enveloped, single-stranded, RNA viruses. Coronaviruses belong to Coronaviridae family which is classified into three groups according to serologic and genetic relationships [179]. The severe acute respiratory syndrome coronavirus (SARS-CoV) belongs to members of group2 [180]. The world is currently in the throes of a pandemic of this kind of coronavirus which is com- 
mon as COVID-19. The ability of Chloroquine to inhibit certain types of Coronaviruses has been explored with excellent results [181] [182].

Several in vitro studies report antiviral activity of Chloroquine and hydroxychloroquine against SARS-CoV-2. In vivo data, although promising, is currently limited to one study with considerable limitations. CQ and HCQ are incorporated in many available protocols guidelines for the treatment of COVID-19 [183]. The efficacy of hydroxychloroquine was improved by combining this drug with azithromycin (an antibiotic) with antiviral properties against other RNA-viruses such as Zikavirus [184]. Also, CQ and HCQ are listed with drugs which may be useful in prophylaxis of COVID-19 [185]

1) Mechanism of CQ/HCQ in treatment of COVID-19

Many Postulates describe the potential mechanisms of action of CQ/HCQ against SARS-CoV-2. CQ may reduce glycosylation angiotensin-converting enzyme 2 (ACE2) by binding to (ACE2) on the cell surface virus to enter the host cells [176]. ACE2 expression is also believed to be up regulated by infection with SARS-CoV-2 [186]. Other hypothesis postulates that CQ might block the production of pro-inflammatory cytokines (such as interleukin-6); thereby blocking the pathway that subsequently leads to acute respiratory distress syndrome (ARDS) [188]. In addition to the fact that some viruses enter host cells through endocytosis using vesicles called endosomes. Virus can replicate through endosomes and released when endosome fuses with the acidic intracellular lysosome. The release of virus is essential for viral replication when endosomes ruptured [187]. The rupture of endosomes is blocked by Chloroquine, which accumulates in lysosomes, interfering with this process [188]. It also believed that Chloroquine raises the $\mathrm{pH}$ level of the endosome, which may interfere with virus entry and/or exit from host cells [189]. Future studies may show and clarify the effectiveness and precise mechanism of action of CQ/HCQ in the treatment of COVID-19.

\subsection{Systemic and Dermatological Disease}

CQ and HCQ were used to treat a variety of skin conditions, the scientific evidence being insufficient and just limited to some isolated case reports. Its usage is recommended in patients with disseminated granuloma annular that does not show a good response or only limited response to topical corticosteroids [190]. Both CQ and HCQ showed an efficacy for long treatment of photosensitive disorders, like actinic recticuloid and chronic actinic dermatitis [191]. CQ and HCQ prevent the progression of graft-versus-shot disease (GVHD) by suppression of $\mathrm{T}$ cells response to foreign antigens and alteration in $\mathrm{T}$ cells production of pro-inflammatory cytokines, such as IL-1, IL6 and TNF-alpha [192].

HCQ is the drug of choice in Patients with localized cutaneous disease who fail to respond to sun protection and topical or intralesional corticosteroid therapy or those with alopecia or disseminated skin lesions [193]. It also effective for other photosensitivity dermatoses like porphyria cutanea tarda (PCT) [194] polymorphous light eruption [195], dermato-myositis (skin manifestations) [196], reticular erythematous mucinosis [197], essner's lymphocytic infiltrate [198] and 
solar urticarial [199], especially in the summer months for patients who fail to respond to sun protection or "hardening" with light therapy [200]. CQ and HCQ are reported to be effective for granulomatous dermatoses, such as sarcoidosis (with neurologic involvement) [201] and disseminated granuloma annulare [202], and may even be used intralesionally [203]. Patients with lymphocytoma cutis, atopic dermatitis, urticarial vasculitis, localized scleroderma, and idiopathic panniculitis have also been treated with CQs [204].

\section{Adverse Effects of Chloroquine (Toxicity)}

Chloroquine when used in standard low doses shows only a few adverse effects, especially when used as prophylaxis for malaria or other systemic disorders. However, acute toxicity by CQ is most frequently encountered if it is given very rapidly by parenteral routes either in therapeutic or overdose. The most common side effects of CQ are retinopathy, neuromayopathy, myopathy, and cardiomyopathy [205] [206] [207].

\subsection{Adverse Effects on the Eye}

It includes two common adverse effects which are; retinopathy and keratopathy. Both of them are associated with long-term administration of CQs [205] [206].

\subsection{Adverse Effects on the Ears}

Ears' adverse reaction of CQs is associated with reversible ototoxicity. Sensorineural hearing loss, a sense of imbalance, and tinnitus were reported [208] [209].

\subsection{Adverse Effects on the Cardiovascular System}

Chloroquine rarely caused cardiovascular side effects, but it may cause severe and irreversible disorders like cardiomyopathy and conduction disturbances [207] [208] [209] [210]. Hemolysis and blood dyscrasias may be rarely occurred [211].

\subsection{Adverse Effects on the Digestive System}

Gastrointestinal discomfort is the most common side effects of Chloroquine. It may be mild to moderate and can be managed by dose reduction. Nausea, vomiting, and diarrhea are the other common gastrointestinal event also might be happened [212] [213].

\subsection{Adverse Effects on the Skin}

Dermatological adverse reaction related to Chloroquine is pruritus, which is appeared more common in dark-skin patient received this agent, because it binds to melanin in the skin [214].

\subsection{Adverse Effects on the Musclo-Skeletal System}

Musculo-skeletal system adverse Chloroquine reaction is a myopathy which re- 
sponsible for muscle weakness, decreased or loss of tendons reflexes [215].

\subsection{Adverse Effects on the Nervous System}

Nervous system Chloroquine's most common adverse effect is a neuromyopathy which is characterized by slowly progressive weakness when it is used for a long time especially in the old patients [216]. Metabolic adverse effect is characterized by hypoglycemic effect; this may lead to convulsion [217].

\section{Conclusion}

Chloroquine antimalarial agents saved the lives of many people in the whole world. It was firstly used almost a century ago, and it is not only used to treat the malarial infection but also it can be used in a variety of autoimmune, inflammatory disorders and microbial infections. In this review, data were collected to demonstrate the multiplicity actions displayed by Chloroquine to improve and treat different inflammatory diseases, immune system disorders, microbial infections and several metabolic disturbances. There is also a role in the recovery of some skin diseases. Through their mechanism, the CQ can produce its action which is demonstrated briefly. Also, toxicity and adverse effects of CQ were showed in this review. Low doses of CQ may be accompanied by low side effects. The relation and benefits of CQ in the treatment of Covid-19 also still need more studies to clarify the mechanism and when it is useful and when it should be arrested. In conclusion, $\mathrm{CQ}$ is a drug of wide applications and needs more studies to precisely determine the exact mechanisms of action that happen by its effect and to develop strategies that will help to be used in the clinic.

\section{Conflicts of Interest}

The authors declare no conflicts of interest regarding the publication of this paper.

\section{References}

[1] Rodriguez-Caruncho, C. and Marsol, I.B. (2014) Antimalarials in Dermatology: Mechanism of Action, Indications, and Side Effects. Actas Dermo-Sifiliográficas (English Edition), 105, 243-252. https://doi.org/10.1016/j.adengl.2012.10.021

[2] Al-Bari, M.A. (2015) Chloroquine Analogues in Drug Discovery: New Directions of Uses, Mechanisms of Actions and Toxic Manifestations from Malaria to Multifarious Diseases. Journal of Antimicrobial Chemotherapy, 70, 1608-1621. https://doi.org/10.1093/jac/dkv018

[3] Mushtaque, M. and Shahjahan (2015) Reemergence of Chloroquine (CQ) Analogs as Multi-Targeting Antimalarial Agents: A Review. European Journal of Medicinal Chemistry, 90, 280-295. https://doi.org/10.1016/j.ejmech.2014.11.022

[4] Rubin, M., Bernstein, H.N. and Zvaifler, N.J. (1963) Studies on the Pharmacology of Chloroquine: Recommendations for the Treatment of Chloroquine Retinopathy. Archives of Ophthalmology, 70, 474-481. https://doi.org/10.1001/archopht.1963.00960050476009

[5] Lesiak, A., Narbutt, J., Kobos, J., Kordek, R., Sysa-Jedrzejowska, A., Norval, M. and 
Wozniacka, A. (2009) Systematic Administration of Chloroquine in Discoid Lupus Erythematosus Reduces Skin Lesions via Inhibition of Angiogenesis. Clinical and Experimental Dermatology: Clinical Dermatology, 34, 570-575. https://doi.org/10.1111/j.1365-2230.2008.03006.x

[6] Dörner, T. (2010) Hydroxychloroquine in SLE: Old Drug, New Perspectives. Nature Reviews Rheumatology, 6, 10-11. https://doi.org/10.1038/nrrheum.2009.235

[7] Joshi, P., Chakraborti, S., Ramirez-Vick, J.E., Ansari, Z.A., Shanker, V., Chakrabarti, P. and Singh, S.P. (2012) The Anticancer Activity of Chloroquine-Gold Nanoparticles against MCF-7 Breast Cancer Cells. Colloids and Surfaces B: Biointerfaces, 95, 195-200. https://doi.org/10.1016/j.colsurfb.2012.02.039

[8] Abdel-Aziz, A.K., Shouman, S., El-Demerdash, E., Elgendy, M. and Abdel-Naim, A.B. (2014) Chloroquine Synergizes Sunitinib Cytotoxicity via Modulating Autophagic, Apoptotic and Angiogenic Machineries. Chemico-Biological Interactions, 217, 28-40. https://doi.org/10.1016/j.cbi.2014.04.007

[9] Warhurst, D.C., Steele, J.C., Adagu, I.S., Craig, J.C. and Cullander, C. (2003) Hydroxychloroquine Is Much Less Active than Chloroquine against Chloroquine-Resistant Plasmodium falciparum, in Agreement with Its Physicochemical Properties. Journal of Antimicrobial Chemotherapy, 52, 188-193.

https://doi.org/10.1093/jac/dkg319

[10] Park, J., Choi, K., Jeong, E., Kwon, D., Benveniste, E.N. and Choi, C. (2004) Reactive Oxygen Species Mediate Chloroquine-Induced Expression of Chemokines by Human Astroglial Cells. Glia, 47, 9-20. https://doi.org/10.1002/glia.20017

[11] Thomé, R., Lopes, S.C., Costa, F.T. and Verinaud, L. (2013) Chloroquine: Modes of Action of an Undervalued Drug. Immunology Letters, 153, 50-57.

https://doi.org/10.1016/j.imlet.2013.07.004

[12] Verbaanderd, C., Maes, H., Schaaf, M.B., Sukhatme, V.P., Pantziarka, P., Sukhatme, V., Agostinis, P. and Bouche, G. (2017) Repurposing Drugs in Oncology (ReDO)-Chloroquine and Hydroxychloroquine as Anti-Cancer Agents. eCancer Medical Science, 11. https://doi.org/10.3332/ecancer.2017.781

[13] Costedoat-Chalumeau, N., Hulot, J.S., Amoura, Z., Delcourt, A., Maisonobe, T., Dorent, R., Bonnet, N., Sablé, R., Lechat, P., Wechsler, B. and Piette, J.C. (2007) Cardiomyopathy Related to Antimalarial Therapy with Illustrative Case Report. Cardiology, 107, 73-80. https://doi.org/10.1159/000094079

[14] McChesney, E.W. (1983) Animal Toxicity and Pharmacokinetics of Hydroxychloroquine Sulfate. The American Journal of Medicine, 75, 11-18.

https://doi.org/10.1016/0002-9343(83)91265-2

[15] Liu, J., Cao, R., Xu, M., Wang, X., Zhang, H., Hu, H., Li, Y., Hu, Z., Zhong, W. and Wang, M. (2020) Hydroxychloroquine, a Less Toxic Derivative of Chloroquine, Is Effective in Inhibiting SARS-CoV-2 Infection in Vitro. Cell Discovery, 6, Article No. 16. https://doi.org/10.1038/s41421-020-0156-0

[16] Ngabire, D. and Kim, G.D. (2017) Autophagy and Inflammatory Response in the Tumor Microenvironment. International Journal of Molecular Sciences, 18, 2016. https://doi.org/10.3390/ijms18092016

[17] White, E. (2015) The Role for Autophagy in Cancer. The Journal of Clinical Investigation, 125, 42-46. https://doi.org/10.1172/JCI73941

[18] Cuervo, A.M. and Wong, E. (2014) Chaperone-Mediated Autophagy: Roles in Disease and Aging. Cell Research, 24, 92-104. https://doi.org/10.1038/cr.2013.153

[19] Waite, K.A., De-La Mota-Peynado, A., Vontz, G. and Roelofs, J. (2016) Starvation Induces Proteasome Autophagy with Different Pathways for Core and Regulatory 
Particles. Journal of Biological Chemistry, 291, 3239-3253. https://doi.org/10.1074/jbc.M115.699124

[20] Frake, R.A., Ricketts, T., Menzies, F.M. and Rubinsztein, D.C. (2015) Autophagy and Neurodegeneration. The Journal of Clinical Investigation, 125, 65-74. https://doi.org/10.1172/JCI73944

[21] Deretic, V., Kimura, T., Timmins, G., Moseley, P., Chauhan, S. and Mandell, M. (2015) Immunologic Manifestations of Autophagy. The Journal of Clinical Investigation, 125, 75-84. https://doi.org/10.1172/JCI73945

[22] Wang, R.C., Wei, Y., An, Z., Zou, Z., Xiao, G., Bhagat, G., White, M., Reichelt, J. and Levine, B. (2012) Akt-Mediated Regulation of Autophagy and Tumorigenesis through Beclin 1 Phosphorylation. Science, 338, 956-959. https://doi.org/10.1126/science.1225967

[23] Cicchini, M., Chakrabarti, R., Kongara, S., Price, S., Nahar, R., Lozy, F., Zhong, H., Vazquez, A., Kang, Y. and Karantza, V. (2014) Autophagy Regulator BECN1 Suppresses Mammary Tumorigenesis Driven by WNT1 Activation and Following Parity. Autophagy, 10, 2036-2052. https://doi.org/10.4161/auto.34398

[24] Lim, K.H. and Staudt, L.M. (2013) Toll-Like Receptor Signaling. Cold Spring Harbor Perspectives in Biology, 5, a011247. https://doi.org/10.1101/cshperspect.a011247

[25] Salminen, A., Kaarniranta, K. and Kauppinen, A. (2013) Beclin 1 Interactome Controls the Crosstalk between Apoptosis, Autophagy and Inflammasome Activation: Impact on the Aging Process. Ageing Research Reviews, 12, 520-534. https://doi.org/10.1016/j.arr.2012.11.004

[26] White, E. (2012) Deconvoluting the Context-Dependent Role for Autophagy in Cancer. Nature Reviews Cancer, 12, 401-410. https://doi.org/10.1038/nrc3262

[27] Galluzzi, L., Kepp, O., Vander Heiden, M.G. and Kroemer, G. (2013) Metabolic Targets for Cancer Therapy. Nature Reviews Drug Discovery, 12, 829-846. https://doi.org/10.1038/nrd4145

[28] Mathew, R., Kongara, S., Beaudoin, B., Karp, C.M., Bray, K., Degenhardt, K., Chen, G., Jin, S. and White, E. (2007) Autophagy Suppresses Tumor Progression by Limiting Chromosomal Instability. Genes \& Development, 21, 1367-1381. https://doi.org/10.1101/gad.1545107

[29] Xie, R., Wang, F., McKeehan, W.L. and Liu, L. (2011) Autophagy Enhanced by Microtubule-and Mitochondrion-Associated MAP1S Suppresses Genome Instability and Hepatocarcinogenesis. Cancer Research, 71, 7537-7546. https://doi.org/10.1158/0008-5472.CAN-11-2170

[30] Rello-Varona, S., Lissa, D., Shen, S., Niso-Santano, M., Senovilla, L., Mariño, G., Vitale, I., Jemaá, M., Harper, F., Pierron, G. and Castedo, M. (2012) Autophagic Removal of Micronuclei. Cell Cycle, 11, 170-176. https://doi.org/10.4161/cc.11.1.18564

[31] Liu, H., He, Z., von Rütte, T., Yousefi, S., Hunger, R.E. and Simon, H.U. (2013) Down-Regulation of Autophagy-Related Protein 5 (ATG5) Contributes to the Pathogenesis of Early-Stage Cutaneous Melanoma. Science Translational Medicine, 5, 202ra123.https://doi.org/10.1126/scitranslmed.3005864

[32] Karantza-Wadsworth, V., Patel, S., Kravchuk, O., Chen, G., Mathew, R., Jin, S. and White, E. (2007) Autophagy Mitigates Metabolic Stress and Genome Damage in Mammary Tumorigenesis. Genes \& Development, 21, 1621-1635. https://doi.org/10.1101/gad.1565707

[33] Yang, S., Wang, X., Contino, G., Liesa, M., Sahin, E., Ying, H., Bause, A., Li, Y., 
Stommel, J.M., Dell'Antonio, G. and Mautner, J. (2011) Pancreatic Cancers Require Autophagy for Tumor Growth. Genes \& Development, 25, 717-729. https://doi.org/10.1101/gad.2016111

[34] Jain, A., Lamark, T., Sjøttem, E., Larsen, K.B., Awuh, J.A., Øvervatn, A., McMahon, M., Hayes, J.D. and Johansen, T. (2010) p62/SQSTM1 Is a Target Gene for Transcription Factor NRF2 and Creates a Positive Feedback Loop by Inducing Antioxidant Response Element-Driven Gene Transcription. Journal of Biological Chemistry, 285, 22576-22591. https://doi.org/10.1074/jbc.M110.118976

[35] Inami, Y., Waguri, S., Sakamoto, A., Kouno, T., Nakada, K., Hino, O., Watanabe, S., Ando, J., Iwadate, M., Yamamoto, M. and Lee, M.S. (2011) Persistent Activation of Nrf2 through p62 in Hepatocellular Carcinoma Cells. Journal of Cell Biology, 193, 275-284. https://doi.org/10.1083/jcb.201102031

[36] Vacchelli, E., Aranda, F., Eggermont, A., Galon, J., Sautès-Fridman, C., Cremer, I., Zitvogel, L., Kroemer, G. and Galluzzi, L. (2014) Trial Watch: Chemotherapy with Immunogenic Cell Death Inducers. Oncoimmunology, 3, e27878. https://doi.org/10.4161/onci.27878

[37] Vacchelli, E., Senovilla, L., Eggermont, A., Fridman, W.H., Galon, J., Zitvogel, L., Kroemer, G. and Galluzzi, L. (2013) Trial Watch: Chemotherapy with Immunogenic Cell Death Inducers. Oncoimmunology, 2, e23510. https://doi.org/10.4161/onci.23510

[38] Kroemer, G., Galluzzi, L., Kepp, O. and Zitvogel, L. (2013) Immunogenic Cell Death in Cancer Therapy. Annual Review of Immunology, 31, 51-72. https://doi.org/10.1146/annurev-immunol-032712-100008

[39] Michaud, M., Martins, I., Sukkurwala, A.Q., Adjemian, S., Ma, Y., Pellegatti, P., Shen, S., Kepp, O., Scoazec, M., Mignot, G. and Rello-Varona, S. (2011) Autophagy-Dependent Anticancer Immune Responses Induced by Chemotherapeutic Agents in Mice. Science, 334, 1573-1577. https://doi.org/10.1126/science.1208347

[40] Manic, G., Obrist, F., Kroemer, G., Vitale, I. and Galluzzi, L. (2014) Chloroquine and Hydroxychloroquine for Cancer Therapy. Molecular \& Cellular Oncology, 1, e29911. https://doi.org/10.4161/mco.29911

[41] Michaud, M., Xie, X., Bravo-San Pedro, J.M., Zitvogel, L., White, E. and Kroemer, G. (2014) An Autophagy-Dependent Anticancer Immune Response Determines the Efficacy of Melanoma Chemotherapy. Oncoimmunology, 3, e944047. https://doi.org/10.4161/21624011.2014.944047

[42] Fu, L.L., Cheng, Y. and Liu, B. (2013) Beclin-1: Autophagic Regulator and Therapeutic Target in Cancer. The International Journal of Biochemistry \& Cell Biology, 45, 921-924. https://doi.org/10.1016/j.biocel.2013.02.007

[43] Chen, N. and Karantza, V. (2011) Autophagy as a Therapeutic Target in Cancer. Cancer Biology \& Therapy, 11, 157-168. https://doi.org/10.4161/cbt.11.2.14622

[44] Lee, S.J., Silverman, E. and Bargman, J.M. (2011) The Role of Antimalarial Agents in the Treatment of SLE and Lupus Nephritis. Nature Reviews Nephrology, 7, 718. https://doi.org/10.1038/nrneph.2011.150

[45] Maes, H., Rubio, N., Garg, A.D. and Agostinis, P. (2013) Autophagy: Shaping the Tumor Microenvironment and Therapeutic Response. Trends in Molecular Medicine, 19, 428-446. https://doi.org/10.1016/j.molmed.2013.04.005

[46] Carmeliet, P. and Jain, R.K. (2011) Principles and Mechanisms of Vessel Normalization for Cancer and Other Angiogenic Diseases. Nature Reviews Drug Discovery, 10, 417-427. https://doi.org/10.1038/nrd3455

[47] Pantziarka, P., Bouche, G., Meheus, L., Sukhatme, V. and Sukhatme, V.P. (2014) 
Repurposing Drugs in Oncology (ReDO)-Mebendazole as an Anti-Cancer Agent. eCancer Medical Science, 8. https://doi.org/10.3332/ecancer.2014.485

[48] Dobrowolski, R. and De Robertis, E.M. (2012) Endocytic Control of Growth Factor Signalling: Multivesicular Bodies as Signalling Organelles. Nature Reviews Molecular Cell Biology, 13, 53-60. https://doi.org/10.1038/nrm3244

[49] Inaba, M. and Maruyama, E. (1988) Reversal of Resistance to Vincristine in P388 Leukemia by Various Polycyclic Clinical Drugs, with a Special Emphasis on Quinacrine. Cancer Research, 48, 2064-2067.

[50] Mirzoeva, O.K., Hann, B., Hom, Y.K., Debnath, J., Aftab, D., Shokat, K. and Korn, W.M. (2011) Autophagy Suppression Promotes Apoptotic Cell Death in Response to Inhibition of the PI3K-mTOR Pathway in Pancreatic Adenocarcinoma. Journal of Molecular Medicine, 89, 877-889. https://doi.org/10.1007/s00109-011-0774-y

[51] Li, H., Jin, X., Zhang, Z., Xing, Y. and Kong, X. (2013) Inhibition of Autophagy Enhances Apoptosis Induced by the PI3K/AKT/mTor Inhibitor NVP-BEZ235 in Renal Cell Carcinoma Cells. Cell Biochemistry and Function, 31, 427-433. https://doi.org/10.1002/cbf.2917

[52] Zhang, Y., Cheng, Y., Ren, X., Zhang, L., Yap, K.L., Wu, H., Patel, R., Liu, D., Qin, Z.H., Shih, I.M. and Yang, J.M. (2012) NAC1 Modulates Sensitivity of Ovarian Cancer Cells to Cisplatin by Altering the HMGB1-Mediated Autophagic Response. Oncogene, 31, 1055-1064. https://doi.org/10.1038/onc.2011.290

[53] Kim, E.L., Wüstenberg, R., Rübsam, A., Schmitz-Salue, C., Warnecke, G., Bücker, E.M., Pettkus, N., Speidel, D., Rohde, V., Schulz-Schaeffer, W. and Deppert, W. (2010) Chloroquine Activates the p53 Pathway and Induces Apoptosis in Human Glioma Cells. Neuro-Oncology, 12, 389-400.

https://doi.org/10.1093/neuonc/nop046

[54] Loehberg, C.R., Thompson, T., Kastan, M.B., Maclean, K.H., Edwards, D.G., Kittrell, F.S., Medina, D., Conneely, O.M. and O’Malley, B.W. (2007) Ataxia Telangiectasia-Mutated and p53 Are Potential Mediators of Chloroquine-Induced Resistance to Mammary Carcinogenesis. Cancer Research, 67, 12026-12033. https://doi.org/10.1158/0008-5472.CAN-07-3058

[55] Zaidi, A.U., McDonough, J.S., Klocke, B.J., Latham, C.B., Korsmeyer, S.J., Flavell, R.A., Schmidt, R.E. and Roth, K.A. (2001) Chloroquine-Induced Neuronal Cell Death Is p53 and Bcl-2 Family-Dependent but Caspase-Independent. Journal of Neuropathology \& Experimental Neurology, 60, 937-945. https://doi.org/10.1093/jnen/60.10.937

[56] Mohamed, M.M. (2005) Anti-Malarial Chloroquine Stimulate p53-Apoptotic Pathway in Rat Hepatocytes. Journal of the Egyptian Society of Parasitology, 35, 19-32.

[57] Loehberg, C.R., Strissel, P.L., Dittrich, R., Strick, R., Dittmer, J., Dittmer, A., Fabry, B., Kalender, W.A., Koch, T., Wachter, D.L. and Groh, N. (2012) Akt and p53 Are Potential Mediators of Reduced Mammary Tumor Growth by Chloroquine and the mTOR Inhibitor RAD001. Biochemical Pharmacology, 83, 480-488.

https://doi.org/10.1016/j.bcp.2011.11.022

[58] Balic, A., Sørensen, M.D., Trabulo, S.M., Sainz, B., Cioffi, M., Vieira, C.R., Miranda-Lorenzo, I., Hidalgo, M., Kleeff, J., Erkan, M. and Heeschen, C. (2014) Chloroquine Targets Pancreatic Cancer Stem Cells via Inhibition of CXCR4 and Hedgehog Signaling. Molecular Cancer Therapeutics, 13, 1758-1771. https://doi.org/10.1158/1535-7163.MCT-13-0948

[59] Maycotte, P., Aryal, S., Cummings, C.T., Thorburn, J., Morgan, M.J. and Thorburn, A. (2012) Chloroquine Sensitizes Breast Cancer Cells to Chemotherapy Indepen- 
dent of Autophagy. Autophagy, 8, 200-212. https://doi.org/10.4161/auto.8.2.18554

[60] Bakkenist, C.J. and Kastan, M.B. (2003) DNA Damage Activates ATM through Intermolecular Autophosphorylation and Dimer Dissociation. Nature, 421, 499-506. https://doi.org/10.1038/nature01368

[61] Wenzel, N.I., Chavain, N., Wang, Y., Friebolin, W., Maes, L., Pradines, B., Lanzer, M., Yardley, V., Brun, R., Herold-Mende, C. and Biot, C. (2010) Antimalarial versus Cytotoxic Properties of Dual Drugs Derived from 4-Aminoquinolines and Mannich Bases: Interaction with DNA. Journal of Medicinal Chemistry, 53, 3214-3226. https://doi.org/10.1021/jm9018383

[62] Solomon, V.R. and Lee, H. (2009) Chloroquine and Its Analogs: A New Promise of an Old Drug for Effective and Safe Cancer Therapies. European Journal of Pharmacology, 625, 220-233. https://doi.org/10.1016/j.ejphar.2009.06.063

[63] Cuomo, F., Altucci, L. and Cobellis, G. (2019) Autophagy Function and Dysfunction: Potential Drugs as Anti-Cancer Therapy. Cancers, 11, 1465. https://doi.org/10.3390/cancers11101465

[64] Esdaile, J.M., Koehler, B.E., Suarez-Almazor, M., Easterbrook, M., Jamali, F., Petty, R.E., Koehn, C., Koren, G., Sauder, D., MacDougall, B. and Rosenberg, E. (2000) Canadian Consensus Conference on Hydroxychloroquine. Journal of Rheumatology, 27, 2919-2921.

[65] Gladman, D.D. (1998) Aspects of Use of Antimalarials in Systemic Lupus Erythematosus. Journal of Rheumatology, 25, 983-985.

[66] Scofield, R.H. and Oates, J.C. (2009) The Place of William Osler in the Description of Systemic Lupus Erythematosus. The American Journal of the Medical Sciences, 338, 409-412.

[67] Momose, Y., Arai, S., Eto, H., Kishimoto, M. and Okada, M. (2013) Experience with the Use of Hydroxychloroquine for the Treatment of Lupus Erythematosus. The Journal of Dermatology, 40, 94-97. https://doi.org/10.1111/1346-8138.12005

[68] Potvin, F., Petitclerc, E., Marceau, F. and Poubelle, P.E. (1997) Mechanisms of Action of Antimalarials in Inflammation: Induction of Apoptosis in Human Endothelial Cells. The Journal of Immunology, 158, 1872-1879.

[69] Kuhn, A., Ruland, V. and Bonsmann, G. (2011) Cutaneous lupus Erythematosus: Update of Therapeutic Options: Part II. Journal of the American Academy of Dermatology, 65, e195-e213. https://doi.org/10.1016/j.jaad.2010.06.017

[70] Prete, M., Racanelli, V., Digiglio, L., Vacca, A., Dammacco, F. and Perosa, F. (2011) Extra-Articular Manifestations of Rheumatoid Arthritis: An Update. Autoimmunity Reviews, 11, 123-131. https://doi.org/10.1016/j.autrev.2011.09.001

[71] Cimmino, M.A., Parisi, M., Moggiana, G., Mela, G.S. and Accardo, S. (1998) Prevalence of Rheumatoid Arthritis in Italy: The Chiavari Study. Annals of the Rheumatic Diseases, 57, 315-318. https://doi.org/10.1136/ard.57.5.315

[72] Carbonell, J., Cobo, T., Balsa, A., Descalzo, M.A. and Carmona, L., for SERAP Study Group (2008) The Incidence of Rheumatoid Arthritis in Spain: Results from a Nationwide Primary Care Registry. Rheumatology, 47, 1088-1092. https://doi.org/10.1093/rheumatology/ken205

[73] Plenge, R.M. (2009) Rheumatoid Arthritis Genetics: 2009 Update. Current Rheumatology Reports, 11, 351-356.

[74] Smolen, J.S. and Steiner, G. (2003) Therapeutic Strategies for Rheumatoid Arthritis. Nature Reviews Drug Discovery, 2, 473-488.

[75] O'Dell, J.R. (2004) Therapeutic Strategies for Rheumatoid Arthritis. New England 
Journal of Medicine, 350, 2591-2602. https://doi.org/10.1056/NEJMra040226

[76] Smolen, J.S., Aletaha, D., Koeller, M., Weisman, M.H. and Emery, P. (2007) New Therapies for Treatment of Rheumatoid Arthritis. The Lancet, 370, 1861-1874. https://doi.org/10.1016/S0140-6736(07)60784-3

[77] Miao, C.G., Yang, Y.Y., He, X., Li, X.F., Huang, C., Huang, Y., Zhang, L., Lv, X.W., Jin, Y. and Li, J. (2013) Wnt Signaling Pathway in Rheumatoid Arthritis, with Special Emphasis on the Different Roles in Synovial Inflammation and Bone Remodeling. Cellular Signalling, 25, 2069-2078. https://doi.org/10.1016/j.cellsig.2013.04.002

[78] Rainsford, K.D., Parke, A.L., Clifford-Rashotte, M. and Kean, W.F. (2015) Therapy and Pharmacological Properties of Hydroxychloroquine and Chloroquine in Treatment of Systemic Lupus Erythematosus, Rheumatoid Arthritis and Related Diseases. Inflammopharmacology, 23, 231-269.

https://doi.org/10.1007/s10787-015-0239-y

[79] Circu, M., Cardelli, J., Barr, M., O’Byrne, K., Mills, G. and El-Osta, H. (2017) Modulating Lysosomal Function through Lysosome Membrane Permeabilization or Autophagy Suppression Restores Sensitivity to Cisplatin in Refractory Non-Small-Cell Lung Cancer Cells. PLoS ONE, 12, e0184922. https://doi.org/10.1371/journal.pone.0184922

[80] Mauthe, M., Orhon, I., Rocchi, C., Zhou, X., Luhr, M., Hijlkema, K.J., Coppes, R.P., Engedal, N., Mari, M. and Reggiori, F. (2018) Chloroquine Inhibits Autophagic Flux by Decreasing Autophagosome-Lysosome Fusion. Autophagy, 14, 1435-1455. https://doi.org/10.1080/15548627.2018.1474314

[81] Zhang, X., Wu, J., Du, F., Xu, H., Sun, L., Chen, Z., Brautigam, C.A., Zhang, X. and Chen, Z.J. (2014) The Cytosolic DNA Sensor cGAS Forms an Oligomeric Complex with DNA and Undergoes Switch-Like Conformational Changes in the Activation Loop. Cell Reports, 6, 421-430. https://doi.org/10.1016/j.celrep.2014.01.003

[82] Zhang, X., Shi, H., Wu, J., Zhang, X., Sun, L., Chen, C. and Chen, Z.J. (2013) Cyclic GMP-AMP Containing Mixed Phosphodiester Linkages Is an Endogenous High-Affinity Ligand for STING. Molecular Cell, 51, 226-235. https://doi.org/10.1016/j.molcel.2013.05.022

[83] Shu, C., Li, X. and Li, P. (2014) The Mechanism of Double-Stranded DNA Sensing through the cGAS-STING Pathway. Cytokine \& Growth Factor Reviews, 25, 641-648. https://doi.org/10.1016/j.cytogfr.2014.06.006

[84] An, J., Woodward, J.J., Sasaki, T., Minie, M. and Elkon, K.B. (2015) Cutting Edge: Antimalarial Drugs Inhibit IFN- $\beta$ Production through Blockade of Cyclic GMP-AMP Synthase-DNA Interaction. The Journal of Immunology, 194, 4089-4093. https://doi.org/10.4049/jimmunol.1402793

[85] Dijkmans, B.A. and Verweij, C.L. (1997) Chloroquine and Hydroxychloroquine Equally Affect Tumor Necrosis Factor-Alpha, Interleukin 6, and Interferon-Gamma Production by Peripheral Blood Mononuclear Cells. The Journal of Rheumatology, 24, 55-60.

[86] Famaey, J.P., Fontaine, J. and Reuse, J. (1975) Inhibiting Effects of Morphine, Chloroquine, Nonsteroidal and Steroidal Anti-Inflammatory Drugs on Electrically-Induced Contractions of Guinea-Pig Ileum and the Reversing Effect of Prostaglandins. Agents and Actions, 5, 354-358. https://doi.org/10.1007/BF02205242

[87] Ruzicka, T. and Printz, M.P. (1982) Arachidonic Acid Metabolism in Guinea Pig Skin: Effects of Chloroquine. Agents and Actions, 12, 527-529. https://doi.org/10.1007/BF01965938

[88] Gibson, T., Emery, P., Armstrong, R.D., Crisp, A.J. and Panayi, G.S. (1987) Com- 
bined D-Penicillamine and Chloroquine Treatment of Rheumatoid Arthritis-A Comparative Study. Rheumatology, 26, 279-284. https://doi.org/10.1093/rheumatology/26.4.279

[89] Rosamond, W. (2008) 2008 Update: A Report from the American Heart Association Statistics Committee and Stroke Statistics Subcommittee. Circulation, 117, e25-146.

[90] Lloyd-Jones, D.M., Wang, T.J., Leip, E.P., Larson, M.G., Levy, D., Vasan, R.S., D’Agostino, R.B., Massaro, J.M., Beiser, A., Wolf, P.A. and Benjamin, E.J. (2004) Lifetime Risk for Development of Atrial Fibrillation: The Framingham Heart Study. Circulation, 110, 1042. https://doi.org/10.1161/01.CIR.0000140263.20897.42

[91] Fuster, V., Rydén, L.E., Cannom, D.S., Crijns, H.J., Curtis, A.B., Ellenbogen, K.A., Halperin, J.L., Le Heuzey, J.Y., Kay, G.N., Lowe, J.E. and Olsson, S.B. (2006) Acc/aha/esc 2006 Guidelines for the Management of Patients with Atrial Fibrillation: A Report of the American College of Cardiology/American Heart Association Task Force on Practice Guidelines and the European Society of Cardiology Committee for Practice Guidelines (Writing Committee to Revise the 2001 Guidelines for the Management of Patients with Atrial Fibrillation): Developed in Collaboration with the European Heart Rhythm Association and the Heart Rhythm Society. Circulation, 114, e257-e354. https://doi.org/10.1093/eurheartj/ehm315

[92] Atienza, F., Almendral, J., Moreno, J., Vaidyanathan, R., Talkachou, A., Kalifa, J., Arenal, A., Villacastín, J.P., Torrecilla, E.G., Sánchez, A. and Ploutz-Snyder, R. (2006) CLINICAL PERSPECTIVE. Circulation, 114, 2434-2442.

[93] Mandapati, R., Skanes, A., Chen, J., Berenfeld, O. and Jalife, J. (2000) Stable Microreentrant Sources as a Mechanism of Atrial Fibrillation in the Isolated Sheep Heart. Circulation, 101, 194-199. https://doi.org/10.1161/01.CIR.101.2.194

[94] Kalifa, J., Jalife, J., Zaitsev, A.V., Bagwe, S., Warren, M., Moreno, J., Berenfeld, O. and Nattel, S. (2003) Intra-Atrial Pressure Increases Rate and Organization of Waves Emanating from the Superior Pulmonary Veins during Atrial Fibrillation. Circulation, 108, 668-671. https://doi.org/10.1161/01.CIR.0000086979.39843.7B

[95] Burrell Jr., Z.L. and Martinez, A.C. (1958) Chloroquine and Hydroxychloroquine in the Treatment of Cardiac Arrhythmias. The New England Journal of Medicine, 258, 798-800. https://doi.org/10.1056/NEJM195804172581608

[96] Sanchez-Chapula, J.A., Salinas-Stefanon, E., Torres-Jacome, J., Benavides-Haro, D.E. and Navarro-Polanco, R.A. (2001) Blockade of Currents by the Antimalarial Drug Chloroquine in Feline Ventricular Myocytes. Journal of Pharmacology and Experimental Therapeutics, 297, 437-445.

[97] Dharmashankar, K. and Widlansky, M.E. (2010) Vascular Endothelial Function and Hypertension: Insights and Directions. Current Hypertension Reports, 12, 448-455. https://doi.org/10.1007/s11906-010-0150-2

[98] Okuda, T. and Grollman, A. (1967) Passive Transfer of Autoimmune Induced Hypertension in the Rat by Lymph Node Cells. Texas Reports on Biology and Medicine, 25, 257-264.

[99] Mathis, K.W., Broome, H.J. and Ryan, M.J. (2014) Autoimmunity: An Underlying Factor in the Pathogenesis of Hypertension. Current Hypertension Reports, 16, Article No.: 424. https://doi.org/10.1007/s11906-014-0424-1

[100] McCarthy, C.G., Goulopoulou, S., Wenceslau, C.F., Spitler, K., Matsumoto, T. and Webb, R.C. (2014) Toll-Like Receptors and Damage-Associated Molecular Patterns: Novel Links between Inflammation and Hypertension. American Journal of Physiology-Heart and Circulatory Physiology, 306, H184-H196.

https://doi.org/10.1152/ajpheart.00328.2013 
[101] Chan, C.T., Sobey, C.G., Lieu, M., Ferens, D., Kett, M.M., Diep, H., et al. (2015) Obligatory Role for B Cells in the Development of Angiotensin II-Dependent Hypertension. Hypertension, 66, 1023-1033. https://doi.org/10.1161/HYPERTENSIONAHA.115.05779

[102] Aranow, C. and Ginzler, E.M. (2000) Epidemiology of Cardiovascular Disease in Systemic Lupus Erythematosus. Lupus, 9, 166-169. https://doi.org/10.1191/096120300678828208

[103] Mellana, W.M., Aronow, W.S., Palaniswamy, C. and Khera, S. (2012) Rheumatoid Arthritis: Cardiovascular Manifestations, Pathogenesis, and Therapy. Current Pharmaceutical Design, 18, 1450-1456. https://doi.org/10.2174/138161212799504795

[104] Scherbel, A.L., Schuchter, S.L. and Harrison, J.W. (1957) Comparison of Effects of Two Antimalarial Agents, Hydroxychloroquine Sulfate and Chloroquine Phosphate, in Patients with Rheumatoid Arthitis. Cleveland Clinic Journal of Medicine, 24, 98-104. https://doi.org/10.3949/ccjm.24.2.98

[105] Tye, M.J., White, H., Appel, B. and Ansell, H.B. (1959) Lupus Erythematosus Treated with a Combination of Quinacrine, Hydroxychloroquine and Chloroquine. The New England Journal of Medicine, 260, 63-66. https://doi.org/10.1056/NEJM195901082600203

[106] Croyle, L. and Morand, E.F. (2015) Optimizing the Use of Existing Therapies in Lupus. International Journal of Rheumatic Diseases, 18, 129-137. https://doi.org/10.1111/1756-185X.12551

[107] McCarthy, C.G., Wenceslau, C.F., Goulopoulou, S., Ogbi, S., Matsumoto, T. and Webb, R.C. (2016) Autoimmune Therapeutic Chloroquine Lowers Blood Pressure and Improves Endothelial Function in Spontaneously Hypertensive Rats. Pharmacological Research, 113, 384-394. https://doi.org/10.1016/j.phrs.2016.09.008

[108] McCarthy, C.G., Wenceslau, C.F., Goulopoulou, S., Baban, B., Matsumoto, T. and Webb, R.C. (2017) Chloroquine Suppresses the Development of Hypertension in Spontaneously Hypertensive Rats. American Journal of Hypertension, 30, 173-181. https://doi.org/10.1093/ajh/hpw113

[109] Gomez-Guzman, M., Jimenez, R., Romero, M., Sanchez, M., Zarzuelo, M.J., Gomez-Morales, M., et al. (2014) Chronic Hydroxychloroquine Improves Endothelial Dysfunction and Protects Kidney in a Mouse Model of Systemic Lupus Erythematosus. Hypertension, 64, 330-337. https://doi.org/10.1161/HYPERTENSIONAHA.114.03587

[110] WHO (1999) Definition, Diagnosis, and Classification of Diabetes Mellitus and Its Complications-Report of a WHO Consultation. World Health Organization, Geneva.

[111] Karimulla, S.K. and Kumar, B.P. (2011) Anti-Diabetic and Anti-Hyperlipidemic Activity of Bark of Bruguiera gymnorrhiza on Streptozotocin-Induced Diabetic Rats. Asian Journal of Pharmaceutical Science \& Technology, 1, 4-7.

[112] Rynes, R.I. (1997) Antimalarial Drugs in the Treatment of Rheumatological Diseases. Rheumatology, 36, 799-805. https://doi.org/10.1093/rheumatology/36.7.799

[113] Mohammady, M, Amini, M.A. and Ghafghazi, T. (2002) Effect of Chloroquine on Diabetes Control in Type 2 Diabetic Patients. Iranian Journal of Endocrinology and Metabolism, 4, 213-216.

[114] Rekedal, L.R., Massarotti, E., Garg, R., Bhatia, R., Gleeson, T., Lu, B. and Solomon, D.H. (2010) Changes in Glycosylated Hemoglobin after Initiation of Hydroxychloroquine or Methotrexate Treatment in Diabetes Patients with Rheumatic Diseases. 
Arthritis \& Rheumatism, 62, 3569-3573. https://doi.org/10.1002/art.27703

[115] Solomon, D.H., Garg, R., Lu, B., Todd, D.J., Mercer, E., Norton, T. and Massarotti, E. (2014) Effect of Hydroxychloroquine on Insulin Sensitivity and Lipid Parameters in Rheumatoid Arthritis Patients without Diabetes Mellitus: A Randomized, Blinded Crossover Trial. Arthritis Care \& Research, 66, 1246-1251. https://doi.org/10.1002/acr.22285

[116] Hage, M.P., Al-Badri, M.R. and Azar, S.T. (2014) A Favorable Effect of Hydroxychloroquine on Glucose and Lipid Metabolism beyond Its Anti-Inflammatory Role. Therapeutic Advances in Endocrinology and Metabolism, 5, 77-85.

[117] Paul, H. (2018) Managing Uncontrolled Type 2 Diabetes: Role of Hydroxychloroquine in Therapy as AD on Antidiabetic Agent: A Case Study. EC Endocrinology and Metabolic Research, 3, 84-88.

[118] Kobayashi, M., Iwasaki, M. and Shigeta, Y. (1980) Receptor Mediated Insulin Degradation Decreased by Chloroquine in Isolated Rat Adipocytes. The Journal of Biochemistry, 88, 39-44.

[119] Smith, G.D., Amos, T.A.S., Mahler, R. and Peters, T.J. (1987) Effect of Chloroquine on Insulin and Glucose Homoeostasis in Normal Subjects and Patients with Non-Insulin-Dependent Diabetes Mellitus. British Medical Journal (Clinical Research Edition), 294, 465-467. https://doi.org/10.1136/bmj.294.6570.465

[120] Powrie, J.K., Smith, G.D., Shojaee-Moradie, F., Sonksen, P.H. and Jones, R.H. (1991) Mode of Action of Chloroquine in Patients with Non-Insulin-Dependent Diabetes Mellitus. American Journal of Physiology-Endocrinology and Metabolism, 260, E897-E904. https://doi.org/10.1152/ajpendo.1991.260.6.E897

[121] Blazar, B.R., Whitley, C.B., Kitabchi, A.E., Tsai, M.Y., Santiago, J., White, N., Stentz, F.B. and Brown, D.M. (1984) In Vivo Chloroquine-Induced Inhibition of Insulin Degradation in a Diabetic Patient with Severe Insulin Resistance. Diabetes, 33, 1133-1137.

[122] Kumar, V., Singh, M.P., Singh, A.P., Pandey, M.S., Kumar, S. and Kumar, S. (2018) Efficacy and Safety of Hydroxychloroquine When Added to Stable Insulin Therapy in Combination with Metformin and Glimepiride in Patients with Type 2 Diabetes Compare to Sitagliptin. International Journal of Basic \& Clinical Pharmacology, 7, 1959-1964. https://doi.org/10.18203/2319-2003.ijbcp20183930

[123] Chakravorty, S., Purkait, I., Pareek, A. and Talware, A. (2017) Hydroxychloroquine: Looking into the Future. Romanian Journal of Diabetes Nutrition and Metabolic Diseases, 24, 369-375. https://doi.org/10.1515/rjdnmd-2017-0043

[124] Emami, J., Pasutto, F.M., Mercer, J.R. and Jamali, F. (1998) Inhibition of Insulin Metabolism by Hydroxychloroquine and Its Enantiomers in Cytosolic Fraction of Liver Homogenates from Healthy and Diabetic Rats. Life Sciences, 64, 325-335. https://doi.org/10.1016/S0024-3205(98)00568-2

[125] Mercer, E., Rekedal, L., Garg, R., Lu, B., Massarotti, E.M. and Solomon, D.H. (2012) Hydroxychloroquine Improves Insulin Sensitivity in Obese Non-Diabetic Individuals. Arthritis Research \& Therapy, 14, Article No. R135. https://doi.org/10.1186/ar3868

[126] Halaby, M.J., Kastein, B.K. and Yang, D.Q. (2013) Chloroquine Stimulates Glucose Uptake and Glycogen Synthase in Muscle Cells through Activation of Akt. Biochemical and Biophysical Research Communications, 435, 708-713. https://doi.org/10.1016/j.bbrc.2013.05.047

[127] Petri, M., Spence, D.E., Bone, L.R. and Hochberg, M.C. (1992) Coronary Artery Disease Risk Factors in the Johns Hopkins Lupus Cohort: Prevalence, Recognition 
by Patients, and Preventive Practices. Medicine, 71, 291-302. https://doi.org/10.1097/00005792-199209000-00004

[128] Leong, K.H., Koh, E.T., Feng, P.H. and Boey, M.L. (1994) Lipid Profiles in Patients with Systemic Lupus Erythematosus. The Journal of Rheumatology, 21, 1264-1267.

[129] Woźniacka, A., Lesiak, A., Smigielski, J. and Sysa-Jedrzejowska, A. (2005) Chloroquine Influence on Lipid Metabolism and Selected Laboratory Parameters. Przeglad lekarski, 62, 855-859.

[130] Beynen, A., Van Der Molen, A. and Geelen, M. (1981) Inhibition of Hepatic Cholesterol Biosynthesis by Chloroquine. Lipids, 16, 472-474.

https://doi.org/10.1007/BF02535017

[131] Sachet, J.C., Borba, E.F., Bonfa, E., Vinagre, C.G., Silva, V.M. and Maranhao, R.C. (2007) Chloroquine Increases Low-Density Lipoprotein Removal from Plasma in Systemic Lupus Patients. Lupus, 16, 273-278. https://doi.org/10.1177/09612033070160040901

[132] Cairoli, E., Rebella, M., Danese, N., Garra, V. and Borba, E.F. (2012) Hydroxychloroquine Reduces Low-Density Lipoprotein Cholesterol Levels in Systemic Lupus Erythematosus: A Longitudinal Evaluation of the Lipid-Lowering Effect. Lupus, 21, 1178-1182. https://doi.org/10.1177/0961203312450084

[133] McEntegart, A., Capell, H.A., Creran, D., Rumley, A., Woodward, M. and Lowe, G.D. (2001) Cardiovascular Risk Factors, Including Thrombotic Variables, in a Population with Rheumatoid Arthritis. Rheumatology, 40, 640-644.

https://doi.org/10.1093/rheumatology/40.6.640

[134] Shah, M.A., Shah, A.M. and Krishnan, E. (2009) Poor Outcomes after Acute Myocardial Infarction in Systemic Lupus Erythematosus. The Journal of Rheumatology, 36, 570-575. https://doi.org/10.3899/jrheum.080373

[135] Rahman, P., Gladman, D.D., Urowitz, M.B., Yuen, K., Hallett, D. and Bruce, I.N. (1999) The Cholesterol Lowering Effect of Antimalarial Drugs Is Enhanced in Patients with Lupus Taking Corticosteroid Drugs. The Journal of Rheumatology, 26, 325.

[136] King, M.A., Ganley, I.G. and Flemington, V. (2016) Inhibition of Cholesterol Metabolism Underlies Synergy between mTOR Pathway Inhibition and Chloroquine in Bladder Cancer Cells. Oncogene, 35, 4518-4528. https://doi.org/10.1038/onc.2015.511

[137] Zhou, B., Xia, Y. and She, J. (2020) Dysregulated Serum Lipid Profile and Its Correlation to Disease Activity in Young Female Adults Diagnosed with Systemic Lupus Erythematosus: A Cross-Sectional Study. Lipids in Health and Disease, 19, Article No. 40. https://doi.org/10.1186/s12944-020-01232-8

[138] Mercado, M.V., Munoz-Valle, J.F., Santos, A., Bernard-Medina, A.G., Martinez-Bonilla, G., Paczka, J.A., Ruiz-García, H., Orozco-Alcalá, J., Orozco-Barocio, G., Quezada-Arellano, D. and Gurrola-Díaz, C. (2002) Evaluation of Lipid Profile, Macular Toxicity and Clinical Manifestations According to APO E Genotype in Systemic Lupus Erythematosus and Rheumatoid Arthritis Patients Treated with Chloroquine. Scandinavian Journal of Rheumatology, 31, 32-37.

https://doi.org/10.1080/030097402317255345

[139] Hodis, H.N., Quismorio Jr., F.P., Wickham, E. and Blankenhorn, D.H. (1993) The Lipid, Lipoprotein, and Apolipoprotein Effects of Hydroxychloroquine in Patients with Systemic Lupus Erythematosus. The Journal of Rheumatology, 20, 661-665.

[140] Beynen, A.C. (1986) Could Chloroquine Be of Value in the Treatment of Hypercholesterolemia? Artery, 13, 340-351. 
[141] Edwards, M.H., Pierangeli, S., Liu, X., Barker, J.H., Anderson, G. and Harris, E.N. (1997) Hydroxychloroquine Reverses Thrombogenic Properties of Antiphospholipid Antibodies in Mice. Circulation, 96, 4380-4384. https://doi.org/10.1161/01.CIR.96.12.4380

[142] Lafyatis, R., York, M. and Marshak-Rothstein, A. (2006) Antimalarial Agents: Closing the Gate on Toll-Like Receptors? Arthritis \& Rheumatism, 54, 3068-3070. https://doi.org/10.1002/art.22157

[143] Emami, J., Gerstein, H.C., Pasutto, F.M., et al. (1999) Insulin-Sparing Effect of Hydroxychloroquine in Diabetic Rats Is Concentration Dependent. Canadian Journal of Physiology and Pharmacology, 77, 118-123. https://doi.org/10.1139/y98-146

[144] Fox, R.I. (1993) Mechanism of Action of Hydroxychloroquine as an Antirheumatic Drug. Seminars in Arthritis and Rheumatism, 23, 82-91. https://doi.org/10.1016/S0049-0172(10)80012-5

[145] Ben-Zvi, I., Kivity, S., Langevitz, P., et al. (2012) Hydroxychloroquine: From Malaria to Autoimmunity. Clinical Reviews in Allergy \& Immunology, 42, 145-153. https://doi.org/10.1007/s12016-010-8243-x

[146] Wellems, T.E. and Plowe, C.V. (2001) Chloroquine-Resistant Malaria. The Journal of Infectious Diseases, 184, 770-776. https://doi.org/10.1086/322858

[147] Siswantoro, H., Russell, B., Ratcliff, A., Prasetyorini, B., Chalfein, F., Marfurt, J., Kenangalem, E., Wuwung, M., Piera, K.A., Ebsworth, E.P. and Anstey, N.M. (2011) In Vivo and in Vitro Efficacy of Chloroquine against Plasmodium malariae and $P$. ovale in Papua, Indonesia. Antimicrobial Agents and Chemotherapy, 55, 197-202. https://doi.org/10.1128/AAC.01122-10

[148] O’Neill, P.M., Bray, P.G., Hawley, S.R., Ward, S.A. and Park, B.K. (1998) 4-Aminoquinolines-Past, Present, and Future: A Chemical Perspective. Pharmacology \& Therapeutics, 77, 29-58. https://doi.org/10.1016/S0163-7258(97)00084-3

[149] Rolain, J.M., Colson, P. and Raoult, D. (2007) Recycling of Chloroquine and Its Hydroxyl Analogue to Face Bacterial, Fungal and Viral Infections in the 21st Century. International Journal of Antimicrobial Agents, 30, 297-308. https://doi.org/10.1016/j.ijantimicag.2007.05.015

[150] Hackstadt, T. and Williams, J.C. (1981) Biochemical Stratagem for Obligate Parasitism of Eukaryotic Cells by Coxiella burnetii. Proceedings of the National Academy of Sciences of the United States of America, 78, 3240-3244. https://doi.org/10.1073/pnas.78.5.3240

[151] Ghigo, E., Capo, C., Aurouze, M., Tung, C.H., Gorvel, J.P., Raoult, D. and Mege, J.L. (2002) Survival of Tropheryma whipplei, the Agent of Whipple's Disease, Requires Phagosome Acidification. Infection and Immunity, 70, 1501-1506. https://doi.org/10.1128/IAI.70.3.1501-1506.2002

[152] Byrd, T.F. and Horwitz, M.A. (1991) Chloroquine Inhibits the Intracellular Multiplication of Legionella pneumophila by Limiting the Availability of Iron. A Potential New Mechanism for the Therapeutic Effect of Chloroquine against Intracellular Pathogens. The Journal of Clinical Investigation, 88, 351-357. https://doi.org/10.1172/JCI115301

[153] Fortier, A.H., Leiby, D.A., Narayanan, R.B., et al. (1995) Growth of Francisella tularensis LVS in Macrophages: The Acidic Intracellular Compartment Provides Essential Iron Required for Growth. Infection and Immunity, 63, 1478-1483. https://doi.org/10.1128/IAI.63.4.1478-1483.1995

[154] Raoult, D., Drancourt, M. and Vestris, G. (1990) Bactericidal Effect of Doxycycline Associated with Lysosomotropic Agents on Coxiella burnetii in P388D1 Cells. An- 
timicrobial Agents and Chemotherapy, 34, 1512-1514. https://doi.org/10.1128/AAC.34.8.1512

[155] Maurin, M. and Raoult, D. (1994) Phagolysosomal Alkalinization and Intracellular Killing of Staphylococcus aureus by Amikacin. The Journal of Infectious Diseases, 169, 330-336. https://doi.org/10.1093/infdis/169.2.330

[156] Nguyen, H.A., Grellet, J., Paillard, D., Dubois, V., Quentin, C. and Saux, M.C. (2006) Factors Influencing the Intracellular Activity of Fluoroquinolones: A Study Using Levofloxacin in a Staphylococcus aureus THP-1 Monocyte Model. Journal of Antimicrobial Chemotherapy, 57, 883-890. https://doi.org/10.1093/jac/dkl079

[157] Eissenberg, L.G., Goldman, W.E. and Schlesinger, P.H. (1995) Histoplasma capsulatum Modulates the Acidification of Phagolysosomes. Journal of Experimental Medicine, 177, 1605-1611. https://doi.org/10.1084/jem.177.6.1605

[158] Strasser, J.E., Newman, S.L., Ciraolo, G.M., Morris, R.E., Howell, M.L. and Dean, G.E. (1999) Regulation of the Macrophage Vacuolar ATPase and Phagosome-Lysosome Fusion by Histoplasma capsulatum. The Journal of Immunology, 162, 6148-6154.

[159] Schafer, M.P. and Dean, G.E. (1993) Cloning and Sequence Analysis of an $\mathrm{H}^{+}$-ATPase-Encoding Gene from the Human Dimorphic Pathogen Histoplasma capsulatum. Gene, 136, 295-300. https://doi.org/10.1016/0378-1119(93)90483-J

[160] Newman, S.L., Gootee, L., Brunner, G. and Deepe Jr., G.S. (1994) Chloroquine Induces Human Macrophage Killing of Histoplasma capsulatum by Limiting the Availability of Intracellular Iron and Is Therapeutic in a Murine Model of Histoplasmosis. The Journal of Clinical Investigation, 93, 1422-1429.

https://doi.org/10.1172/JCI117119

[161] Boelaert, J.R., Appelberg, R., Gomes, M.S., et al. (2001) Experimental Results on Chloroquine and AIDS-Related Opportunistic Infections. Journal of Acquired Immune Deficiency Syndrome, 26, 300-301. https://doi.org/10.1097/00126334-200103010-00017

[162] Levitz, S.M., Harrison, T.S., Tabuni, A. and Liu, X. (1997) Chloroquine Induces Human Mononuclear Phagocytes to Inhibit and Kill Cryptococcus Neoformans by a Mechanism Independent of Iron Deprivation. The Journal of Clinical Investigation, 100, 1640-1646. https://doi.org/10.1172/JCI119688

[163] Levitz, S.M., Nong, S.H., Seetoo, K.F., Harrison, T.S., Speizer, R.A. and Simons, E.R. (1999) Cryptococcus neoformans Resides in an Acidic Phagolysosome of Human Macrophages. Infection and Immunity, 67, 885-890.

https://doi.org/10.1128/IAI.67.2.885-890.1999

[164] Jahn, B., Langfelder, K., Schneider, U., Schindel, C. and Brakhage, A.A. (2002) PKSP-Dependent Reduction of Phagolysosome Fusion and Intracellular Kill of $A s$ pergillus fumigatus Conidiabyhumanmonocyte-Derived Macrophages. Cellular Microbiology, 4, 793-803. https://doi.org/10.1046/j.1462-5822.2002.00228.x

[165] Taramelli, D., Tognazioli, C., Ravagnani, F., Leopardi, O., Giannulis, G. and Boelaert, J.R. (2001) Inhibition of Intramacrophage Growth of Penicillium marneffei by 4-Aminoquinolines. Antimicrobial Agents and Chemotherapy, 45, 1450-1455. https://doi.org/10.1128/AAC.45.5.1450-1455.2001

[166] Sieczkarski, S.B. and Whittaker, G.R. (2002) Dissecting Virus Entry via Endocytosis. Journal of General Virology, 83, 1535-1545.

https://doi.org/10.1099/0022-1317-83-7-1535

[167] Gonzalez-Dunia, D., Cubitt, B. and de la Torre, J.C. (1998) Mechanism of Borna Disease Virus Entry into Cells. Journal of Virology, 72, 783-788.

https://doi.org/10.1128/JVI.72.1.783-788.1998 
[168] Shibata, M., Aoki, H., Tsurumi, T., Sugiura, Y., Nishiyama, Y., Suzuki, S. and Maeno, K. (1983) Mechanism of Uncoating of Influenza B Virus in MDCK Cells: Action of Chloroquine. Journal of General Virology, 64, 1149-1156. https://doi.org/10.1099/0022-1317-64-5-1149

[169] Bishop, N.E. (1998) Examination of Potential Inhibitors of Hepatitis A Virus Uncoating. Intervirology, 41, 261-271. https://doi.org/10.1159/000024948

[170] Miller, D.K. and Lenard, J. (1981) Antihistaminics, Local Anesthetics, and Other Amines as Antiviral Agents. Proceedings of the National Academy of Sciences, 78, 3605-3609. https://doi.org/10.1073/pnas.78.6.3605

[171] Mizui, T., Yamashina, S., Tanida, I., Takei, Y., Ueno, T., Sakamoto, N., Ikejima, K., Kitamura, T., Enomoto, N., Sakai, T. and Kominami, E. (2010) Inhibition of Hepatitis C Virus Replication by Chloroquine Targeting Virus-Associated Autophagy. Journal of Gastroenterology, 45, 195-203. https://doi.org/10.1007/s00535-009-0132-9

[172] Randolph, V.B., Winkler, G. and Stollar, V. (1990) Acidotropic Amines Inhibit Proteolytic Processing of Flavivirus prM Protein. Virology, 174, 450-458. https://doi.org/10.1016/0042-6822(90)90099-D

[173] Savarino, A., Lucia, M.B., Rastrelli, E., Rutella, S., Golotta, C., Morra, E., Tamburrini, E., Perno, C.F., Boelaert, J.R., Sperber, K. and Cauda, R. (2004) Anti-HIV Effects of Chloroquine: Inhibition of Viral Particle Glycosylation and Synergism with Protease Inhibitors. JAIDS Journal of Acquired Immune Deficiency Syndromes, 35, 223-232. https://doi.org/10.1097/00126334-200403010-00002

[174] Naarding, M.A., Baan, E., Pollakis, G. and Paxton, W.A. (2007) Effect of Chloroquine on Reducing HIV-1 Replication in Vitro and the DC-SIGN Mediated Transfer of Virus to CD4+T-Lymphocytes. Retrovirology, 4, Article No.: 6. https://doi.org/10.1186/1742-4690-4-6

[175] Kwiek, J.J., Haystead, T.A. and Rudolph, J. (2004) Kinetic Mechanism of Quinone Oxidoreductase 2 and Its Inhibition by the Antimalarial Quinolines. Biochemistry, 43, 4538-4547. https://doi.org/10.1021/bi035923w

[176] Devaux, C.A., Rolain, J.M., Colson, P. and Raoult, D. (2020) New Insights on the Antiviral Effects of Chloroquine against Coronavirus: What to Expect for COVID-19? International Journal of Antimicrobial Agents, 55, 105938. https://doi.org/10.1016/j.ijantimicag.2020.105938

[177] Savarino, A., Di Trani, L., Donatelli, I., Cauda, R. and Cassone, A. (2006) New Insights into the Antiviral Effects of Chloroquine. The Lancet Infectious Diseases, 6, 67-69. https://doi.org/10.1016/S1473-3099(06)70361-9

[178] Savarino, A., Boelaert, J.R., Cassone, A., Majori, G. and Cauda, R. (2003) Effects of Chloroquine on Viral Infections: An Old Drug against Today's Diseases. The Lancet Infectious Diseases, 3, 722-777. https://doi.org/10.1016/S1473-3099(03)00806-5

[179] Keyaerts, E., Li, S., Vijgen, L., Rysman, E., Verbeeck, J., Van Ranst, M. and Maes, P. (2009) Antiviral Activity of Chloroquine against Human Coronavirus OC43 Infection in Newborn Mice. Antimicrobial Agents and Chemotherapy, 53, 3416-3421. https://doi.org/10.1128/AAC.01509-08

[180] Gorbalenya, A.E., Snijder, E.J. and Spaan, W.J. (2004) Severe Acute Respiratory Syndrome Coronavirus Phylogeny: Toward Consensus. Journal of Virology, 78, 7863-7866. https://doi.org/10.1128/JVI.78.15.7863-7866.2004

[181] Keyaerts, E., Vijgen, L., Maes, P., Neyts, J. and Van Ranst, M. (2004) In Vitro Inhibition of Severe Acute Respiratory Syndrome Coronavirus by Chloroquine. Biochemical and Biophysical Research Communications, 323, 264-268. 
https://doi.org/10.1016/j.bbrc.2004.08.085

[182] Colson, P., Rolain, J.M. and Raoult, D. (2020) Chloroquine for the 2019 Novel Coronavirus SARS-CoV-2. International Journal of Antimicrobial Agents, 55, 105923. https://doi.org/10.1016/j.ijantimicag.2020.105923

[183] Jeevaratnam, K. (2020) Chloroquine and Hydroxychloroquine for COVID-19: Implications for Cardiac Safety. European Heart Journal-Cardiovascular Pharmacotherapy.

[184] Gendrot, M., Javelle, E., Le Dault, E., Clerc, A., Savini, H. and Pradines, B. (2020) Chloroquine as Prophylactic Agent against COVID-19? International Journal of Antimicrobial Agents, 55, 105980. https://doi.org/10.1016/j.ijantimicag.2020.105980

[185] Yazdany, J. and Kim, A.H. (2020) Use of Hydroxychloroquine and Chloroquine during the COVID-19 Pandemic: What Every Clinician Should Know. Annals of Internal Medicine, 172, 754-755.

[186] Wang, P.H. (2020) Increasing Host Cellular Receptor-Angiotensin-Converting Enzyme 2 (ACE2) Expression by Coronavirus May Facilitate 2019-nCoV Infection. BioRxiv, preprint. https://doi.org/10.1101/2020.02.24.963348

[187] Zhang, C., Wu, Z., Li, J.W., Zhao, H. and Wang, G.Q. (2020) The Cytokine Release Syndrome (CRS) of Severe COVID-19 and Interleukin-6 Receptor (IL-6R) Antagonist Tocilizumab May Be the Key to Reduce the Mortality. International Journal of Antimicrobial Agents, 55, 105954.

https://doi.org/10.1016/j.ijantimicag.2020.105954

[188] Golden, E.B., Cho, H.-Y., Hofman, F.M., Louie, S.G., Schönthal, A.H. and Chen, T.C. (2015) Quinoline-Based Antimalarial Drugs: A Novel Class of Autophagy Inhibitors. Neurosurgical Focus, 38, E12.

https://doi.org/10.3171/2014.12.FOCUS14748

[189] Vincent, M.J., Bergeron, E., Benjannet, S., Erickson, B.R., Rollin, P.E., Ksiazek, T.G., Seidah, N.G. and Nichol, S.T. (2005) Chloroquine Is a Potent Inhibitor of SARS Coronavirus Infection and Spread. Virology Journal, 2, Article No. 69. https://doi.org/10.1186/1743-422X-2-69

[190] Masmoudi, A., Abdelmaksoud, W., Turki, H., Hachicha, M., Marrekchi, S., Mseddi, M., Bouassida, S. and Zahaf, A. (2006) Beneficial Effects of Antimalarials in the Treatment of Generalized Granuloma Annular in Children. La Tunisie Medicale, 84, 125-127.

[191] Wolverton, J.E., Soter, N.A. and Cohen, D.E. (2014) The Natural History of Chronic Actinic Dermatitis: An Analysis at a Single Institution in the United States. Dermatitis, 25, 27-31. https://doi.org/10.1097/DER.0000000000000007

[192] Schultz, K.R., Su, W.N., Hsiao, C.C., Doho, G., Jevon, G., Bader, S., MacFarlane, D.E. and Gilman, A.L. (2002) Chloroquine Prevention of Murine MHC-Disparate Acute Graft-versus-Host Disease Correlates with Inhibition of Splenic Response to CpG Oligodeoxynucleotides and Alterations in T-Cell Cytokine Production. Biology of Blood and Marrow Transplantation, 8, 648-655. https://doi.org/10.1053/bbmt.2002.v8.abbmt080648

[193] Company-Quiroga, J., Alique-García, S. and Romero-Maté, A. (2019) Current Insights into the Management of Discoid Lupus Erythematosus. Clinical, Cosmetic and Investigational Dermatology, 12, 721.

[194] Ashton, R.E., Hawk, J.L. and Magnus, I.A. (1984) Low-Dose Oral Chloroquine in the Treatment of Porphyria Cutanea Tarda. British Journal of Dermatology, 111, 609-613. https://doi.org/10.1111/j.1365-2133.1984.tb06632.x

[195] Murphy, G.M., Hawk, J.L. and Magnus, I.A. (1987) Hydroxychloroquine in Poly- 
morphic Light Eruption: A Controlled Trial with Drug and Visual Sensitivity Monitoring. British Journal of Dermatology, 116, 379-386. https://doi.org/10.1111/j.1365-2133.1987.tb05852.x

[196] Callen, J.P. (1985) Dermatomyostis-An Update 1985. Seminars in Dermatology, 4, 114-125.

[197] Balogh, E., Nagy-Vezekenyi, K. and Forizs, E. (1980) REM Syndrome: An Immediate Therapeutic Response to Hydroxychloroquine Sulphate. Acta Dermato-Venereologica, 60, 173-175.

[198] Toonstra, J., Wildschut, A., Boer, J., Smeenk, G., Willemze, R., van der Putte, S.C., Boonstra, H. and van Vloten, W.A. (1989) Jessner's Lymphocytic Infiltration of the Skin: A Clinical Study of 100 Patients. Archives of Dermatology, 125, 1525-1530. https://doi.org/10.1001/archderm.1989.01670230067010

[199] Mathews-Roth, M.M. (1986) Systemic Photoprotection. Dermatologic Clinics, 4, 335-339. https://doi.org/10.1016/S0733-8635(18)30837-4

[200] Swanbeck, G. (1982) Treatment of Photodermatoses. Seminars in Dermatology, 1, 211-216.

[201] Jones, E. and Callen, J.P. (1990) Hydroxychloroquine Is Effective Therapy for Control of Cutaneous Sarcoidal Granulomas. Journal of the American Academy of Dermatology, 23, 487-489. https://doi.org/10.1016/0190-9622(90)70246-E

[202] Carlin, M.C. and Ratz, J.L. (1987) A Case of Generalized Granuloma Annulare Responding to Hydroxychloroquine. Cleveland Clinic Journal of Medicine, 54, 229-232.

[203] Liedtka, J.E. (1996) Intralesional Chloroqnine for the Treatment of Cutaneous Sarcoidosis. International Journal of Dermatology, 35, 682-683. https://doi.org/10.1111/j.1365-4362.1996.tb03710.x

[204] Wolverton, S.E. and Wilkin, J.K., Eds. (1991) Systemic Drugs for Skin Diseases. WB Saunders Company, Philadelphia.

[205] Geamănu, A., Popa-Cherecheanu, A., Marinescu, B., et al. (2014) Retinal Toxicity Associated with Chronic Exposure to Hydroxychloroquine and Its Ocular Screening. Journal of Medicine and Life, 7, 322-326.

[206] Stelton, C.R., Connors, D.B., Walia, S.S. and Walia, H.S. (2013) Hydrochloroquine Retinopathy: Characteristic Presentation with Review of Screening. Clinical Rheumatology, 32, 895-898. https://doi.org/10.1007/s10067-013-2226-2

[207] Yogasundaram, H., Putko, B.N., Tien, J., Paterson, D.I., Cujec, B., Ringrose, J. and Oudit, G.Y. (2014) Hydroxychloroquine-Induced Cardiomyopathy: Case Report, Pathophysiology, Diagnosis, and Treatment. Canadian Journal of Cardiology, 30, 1706-1715. https://doi.org/10.1016/j.cjca.2014.08.016

[208] Bortoli, R. and Santiago, M. (2007) Chloroquine Ototoxicity. Clinical Rheumatology, 26, 1809-1810. https://doi.org/10.1007/s10067-007-0662-6

[209] Coutinho, M.B. and Duarte, I. (2002) Hydroxychloroquine Ototoxicity in a Child with Idiopathic Pulmonary Haemosiderosis. International Journal of Pediatric Otorhinolaryngology, 62, 53-57. https://doi.org/10.1016/S0165-5876(01)00592-4

[210] Tönnesmann, E., Kandolf, R. and Lewalter, T. (2013) Chloroquine Cardiomyopathy-A Review of the Literature. Immunopharmacology and Immunotoxicology, 35, 434-442. https://doi.org/10.3109/08923973.2013.780078

[211] Joyce, E., Fabre, A. and Mahon, N. (2013) Hydroxychloroquine Cardiotoxicity Presenting as a Rapidly Evolving Biventricular Cardiomyopathy: Key Diagnostic Features and Literature Review. European Heart Journal: Acute Cardiovascular Care, 2, 
77-83. https://doi.org/10.1177/2048872612471215

[212] Martins, A.C., Cayotopa, A.D., Klein, W.W., Schlosser, A.R., Silva, A.F., Souza, M.N., Andrade, B.W., Filgueira-Júnior, J.A., Pinto, W.D. and da Silva-Nunes, M. (2015) Side Effects of Chloroquine and Primaquine and Symptom Reduction in Malaria Endemic Area (Mâncio Lima, Acre, Brazil). Interdisciplinary Perspectives on Infectious Diseases, 2015, Article ID: 346853.

https://doi.org/10.1155/2015/346853

[213] Van Beek, M.J. and Piette, W.W. (2001) Antimalarials. Dermatologic Clinics, 19, 147-160. https://doi.org/10.1016/S0733-8635(05)70236-9

[214] Onyeji, C.O. and Ogunbona, F.A. (2001) Pharmacokinetic Aspects of Chloroquine-Induced Pruritus: Influence of Dose and Evidence for Varied Extent of Metabolism of the Drug. European Journal of Pharmaceutical Sciences, 13, 195-201. https://doi.org/10.1016/S0928-0987(01)00108-7

[215] Bolaños-Meade, J., Zhou, L., Hoke, A., Corse, A., Vogelsang, G. and Wagner, K.R. (2005) Hydroxychloroquine Causes Severe Vacuolar Myopathy in a Patient with Chronic Graft-versus-Host Disease. American Journal of Hematology, 78, 306-309. https://doi.org/10.1002/ajh.20294

[216] Tristano, A.G., Falcón, L., Willson, M. and de Oca, I.M. (2004) Seizure Associated with Chloroquine Therapy in a Patient with Systemic Lupus Erythematosus. Rheumatology International, 24, 315-316. https://doi.org/10.1007/s00296-003-0435-8

[217] Sharma, N. and Varma, S. (2003) Unusual Life-Threatening Adverse Drug Effects with Chloroquine in a Young Girl. Journal of Postgraduate Medicine, 49, 187. 